\title{
Impact of Cold Storage Facility Management Regulatory Standards on Firm's Profit Based on Cold Storage Operations Data in the Tema Metropolitan Assembly
}

\author{
Paulina Rita Annan Ziwei Wang* \\ School of Economics and Management \\ Beijing Institute of Graphic Communication, Beijing - 102627; China \\ wangziwei@bigc.edu.cn
}

\begin{abstract}
The Ghana Food and Drug Authority has formulated and implemented cold storage management regulations and standards for over 10 years now, and the effects of cold storage facility firms' in implementing the relevant standards have been fully demonstrated. In the past, research focused on whether to comply with management regulations and standards, and whether compliance or not with regulations and standards would increase the burden on enterprises. Aside from this, while systematic research on the impact of corporate profits is rare, and there is still a lot of controversies in regard to impacts of regulatory standards on cold storage operational efficiency, some scholars believe that regulators only consider customer satisfaction and not the impact on firms' operations and argue that strict compliance with regulatory standards has a negative impact on company profits. Some scholars believe that poorly managed storage facilities and lack of proper maintenance and processing procedures may result in low-quality frozen products, which may force management to destroy or sell them at a price lower than the market price, which will ultimately reduce the profit margin of the company. Based on the above background, this study sought to discuss the impact of cold storage management regulations and standards on corporate profits, which has important theoretical and practical significance. In order to achieve this goal, this study first used the literature research method to summarize the research results of the impact of cold storage management regulations and standards on corporate profits. Based on this, questionnaire surveys and expert interviews were used to conduct research on cold storage companies in Tema Metropolis., data collection was based on the information sought from firms, Regulatory Agencies, and customers, on the impact of cold storage management regulations and standards on firms' profits, all the data gathered were analyzed t with SPSS software and Microsoft Excel. The results showed that about $73 \%$ of people confirmed that the product quality was due to compliance with cold storage management regulations and standards. Under the circumstances, corporate profits will increase. This study also selected the profit data of 15 Tema metropolitan companies in recent years for trend analysis. The results also show that compliance with the cold storage operation supervision on standards is closely related to the firms' profits. Finally, this study puts forward suggestions on the issues that the firms, government, and regulators need to pay attention to in the process of implementing regulations and standards for cold storage management.
\end{abstract}

Keywords: cold storage management; regulations and standards; profit; Tema Metropolis

DOI: $10.7176 / \mathrm{EJBM} / 13-23-02$

Publication date: December $31^{\text {st }} 2021$

\subsection{INTRODUCTION}

Every firm is interested in achieving high profitability and the management of firms tries to focus their efforts on achieving this objective. To be able to attain this objective, there is the need for management to pay much attention to reducing operational costs such as electricity, technology, plant, and machinery (H. Ozgun et al., 2021 $)^{[1]}$, Some firms are therefore finding ways and means to maximize their profitability either by increasing sales or maintaining product quality which is said to be a tool for enhancing profitability through the acceleration of modern technology and compliance. (Chen, Cheng 2017) ${ }^{[2]}$. However, (Zakaria, U. S. (2018) ${ }^{[3]}$ it is stipulated that firms striving to enhance product quality come without negative effect on profitability. Whiles, (Ishii, Y. 2013) ${ }^{[4]}$ in a hypothesis developed also stated that strict policies or regulatory standards aids in maintaining product quality which enhances profitability but in addition claims that rigid policies or extreme strictness tend to have a negative effect on profit. In recent times, Cold Storage management has become one of the critical areas in every country as a way of preserving frozen products amidst this Pandemic era, especially in the fish industry in Ghana. And previous studies in facility management best practices have proved that poorly managed storage facilities and lack of proper maintenance and handling processes may lead to poor quality of frozen products (Schalck, R. 2019) ${ }^{[5]}$ This poor quality may lead to contamination and infection, and as a result, may force management to either destroy or sell below the market price which at the end reduces the profit margin of the business.

Cold storage firms contribute to the economic growth and development of every country in several ways such as food, health, safety, and employment. It is said that the wealth of a nation depends on the good health of the people and this is seen as fundamental to any developmental objectives of a nation. Meaning that when people are 
healthy, they become more productive, and businesses are able to grow leading to the employment of more people, which is helpful in reducing unemployment in the country. Furthermore, considering the critical value of fish as mentioned already, it is clear that both health authorities, national regulators, and the managers of the cold store firms play collaborative roles (Regulators and Authorities, 2020). ${ }^{[6]}$ in ensuring that approved and standard facilities are available for the storage of the excess fish for the citizens. In achieving profit maximization, firms tend to encounter many challenges which are known to be, high taxes, high electricity, transportation cost, high cost of maintenance, and now what has been observed as additional cost of compliance with regulatory standards. The firms think the regulators only think about customer satisfaction without taking into consideration the impact on the firms' operations but does adhering to proper regulatory standards really have any negative impact on the firms' profit. There are numerous laws and policies regarding cold storage operations commonly known in Ghana as Facility Management Regulatory Standards. These standards are implemented by different institutions namely the Food and Drugs Authority, Ghana Standards Authority, Environmental Protection Agency, Department of Factories Inspectorate, Tema Metropolitan Assembly, and Port Health. Each institution has its unique mandate to ensure the health and safety of its customers. However, each institution was established at a different time and for a purpose.

\subsubsection{Study objectives}

According to the above discussion, this study is intended to delineate the impact of Facility Management Regulatory Standards (FMRS) on the firms' profit based on cold storage data

The study aims to achieve the following objectives;

(1) Examine the implementation effect of Facility Management Regulatory Standards of cold storage operations in Ghana.

(2) Find out if adhering to proper regulatory standards has any impact on profit maximization,

(3) Examine the barriers influencing compliance to facility management regulatory standards.

(4) To identify the ways management can employ to minimize operational costs.

(5) To make improvement suggestions to facility management regulatory standards on cold storage firms in Ghana.

The study attempts to answer the following questions

(1) What are the facility management regulatory standards relating to cold storage operations in Ghana?

(2) What is the impact of the relationship between management activities and facility management regulatory standards?

(3) Does adhering to proper regulatory standards have any impact on profit maximization.

(4) What are the barriers influencing compliance to facility management regulatory standards.

(5) To identify the ways management can employ to minimize cost.

\subsection{Research Significance}

1. Theoretical Significance

There have been numerous studies that have been conducted on the fishing industry, which focused on various areas including "segmentation of fish consumers in Belgium and cultural differences as a determination of fish consumption" (MISIR, G. B., KUTLU, S., \& AYYILDIZ, H. (2015) [7], Determination of Fish Consumption Habits of Consumers: Case Study of Mary City, Turkmenistan. Marine Science and Technology Bulletin. (AYDIN, A., \& BASHIMOV, G. 2020) ${ }^{[8]}$, to mention but a few. These researchers, all concentrated on products, consumers, management Best practices, compliance with regulatory standards but failed to look at the cold storage operations and the impact of facility management regulatory standards on the firms' profit. This has recreated a gap in the study which require a considerable effort to bridge in future studies

2. Practical Significance

It is with the hope that this study can help provide a reference for the management of Cold storage firms in reality, and to help the relevant companies to recognize the barriers of influencing compliance to facility management regulatory standards and improve standard management and promote the development of Ghana's fisheries. It will also serve as a guide for workshops and semesters in addressing pertinent issues in cold storage operations. At the same time serving as a guide for investors concerning regulatory standards on cold storage operations in Ghana.

\subsection{Innovation points}

1. Theoretical Innovation

It was found that there were no or very few studies on this specific topic which makes this study innovative because it will add to knowledge and serve as a reference for further research on cold storage operations in Ghana and globally.

\section{Data Innovation}

The study will also serve as data for various firms and regulatory institutions for managerial decisions and strategy formulation. It will also inform investors interested in cold storage operations to know have first-hand information 
on the entry requirement of cold storage operations.

3. Content Innovation

This study was put together with very little and fairly closely related literature and therefore the content is found to be very innovative. There was also an assumption that "in relation to cold storage operations product quality only comes as a result of adhering to Facility Management Regulatory Standards and can also be a factor for determining profitability aside all other factors.

The results proved that the assumption was true. The second assumption was that; there exists a positive relationship between Regulatory Standards and Firms' profit". Both assumptions were affirmed by the results ascertained. The research was also able to construct a framework to help sharpen this study. Finally, the researchers developed an additional acronym FMRS (Facility Management Regulatory Standards.). All these shows that; the content was mostly created by the researcher.

\subsection{CONCEPTUAL FRAMEWORK AND LITERATURE REVIEW}

\subsection{Conceptual Frame Work}

This shows the conceptual framework of cold storage operations in Ghana.

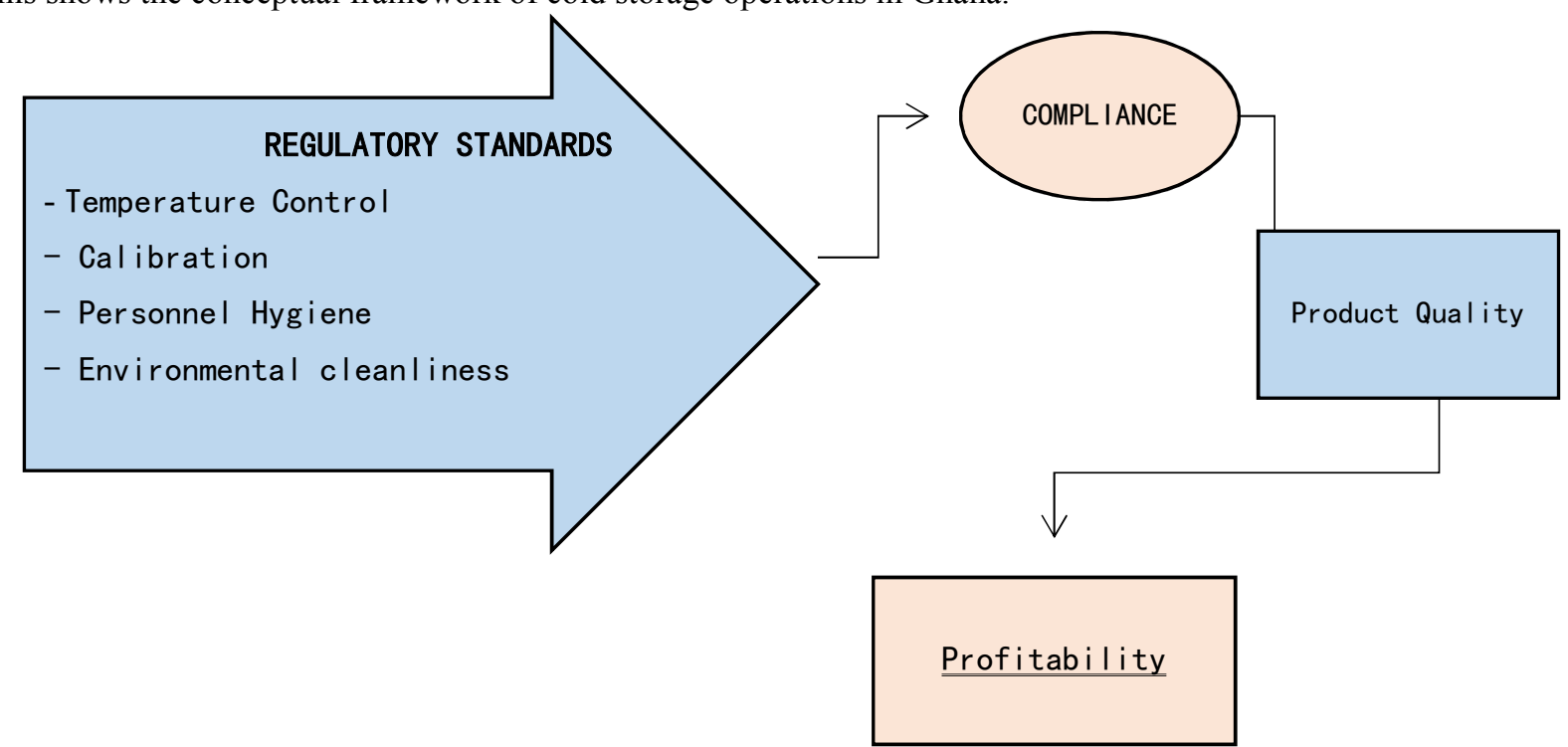

Fig 2.1 FrameWork - Cold Storage Operations. Constructed by Researcher June 2021.

\subsubsection{Regulatory Standards}

Facility Management Regulatory Standards are formulated and implemented to ensure

discipline in the activities of the firms. There are numerous regulatory standards such as ISO (International Standards Organizations) 22000 for food and safety export companies specialized in foodstuff trading, food processing, packaging, and shipping. HACCP certification ensures safety with $100 \%$ quality assurance and the EU (European Union) international standards. In Ghana, there are the Main Standards which is formulated and implemented by the Food and Drugs Authority as stated above the Public Act, 2012, Act 851, Part seven, section 148 , subsection $(2 \mathrm{~g})$, code practice applies to the cold storage of meat and fish to ensure their safety and quality and this code of practice is intended to help the cold storage facility operators comply with the requirements of the FDA to maintain their integrity for their intended purpose. About Cold storage firms there is the need to comply with these standards.

\section{Temperature Control}

For the firm to maintain the product quality it is required that the temperature is maintained at or below -18 degrees Celsius. This can be achieved by frequent monitoring and recording as per the requirement every two hours or at least thrice a day. It can also be said that the products must be stacked in the proper way to ensure air circulation and not too high to block the fans on the machines from working effectively. It is with the assurance that malfunctioning machines can be detected early enough to avoid deterioration. This implies that the temperature of the facility has a direct relationship with the quality of the products in the cold storage facility according to a journal on Food Control by Myn Min Aung et al., (2014), Volume 40, June 2014, Pages 198-207 [11].

\section{Calibration}

It is about the assurance that measures are accurate and within standards. This is a requirement by the Food and Drug Authority and the measurement is done by Ghana Standards Authority who is mandated and equipped to perform that activity. Undesirable results here mean that a firm is operating below standards and may damage the firms' reputation or lead to further audit in the firms' activities. 


\section{Personnel Hygiene}

It is required by the Food and Drugs Authority that all persons handling food must be healthy to avoid contamination and the spread of infectious diseases. It is therefore required that all personnel have a medical test and obtain individual certificates for either T.M.A (Tema Metropolitan Assembly) or Port Health under CAP 78, 908 amended in 1935. It also required that firms provide personnel with PPEs (Personal Protective Equipment) to ensure their health and safety. That is to prevent them from getting cold-related diseases and accidents.

4. Environmental Cleanliness

It is also a requirement that all firms keep the environment in which they operate free from pollution and contamination. EPA (Environmental Protection Agency) ensures that the facilities are prospering positions and are not blocking any drainage. It also ensures that noise from machines and equipment is not disturbing those within that environment. Finally, ensure that spillage and wastewater are properly managed. The Tema Metropolitan Assembly which has a hygiene section is also concerned with environmental hygiene. They ensure that there is proper waste management, availability of water, and a clean washroom on the firms' premises. The assembly as well ensures that the environment is fumigated to avoid and prevent rodents from biting off the products and EPA is equipped to do such fumigation.

\subsubsection{Compliance with Standards}

It is the process of adhering to policies, standards, or rules governing and firm or a country, or an individual. One of the principles to consider in Business administration is the Principle of Discipline by Henri Fayal which talks about sincerity, obedience, respect of authority, and observance of rules and regulations of the enterprise. However, these principles do not only apply to subordinates obeying and respecting orders but management observing the rules and regulations that guide their operations as well. In addition to the above, the word "administer" which is derived from the Latin word "Administration", means to care for people or to manage affairs, as such managerial processes, actions and control should all be for the express purpose of achieving predetermined goals in this case, product quality. And Product Quality simply refers to the incorporation of some features that can meet customer needs and give customer satisfaction. Therefore, cold storage firms need to comply with regulatory standards in the entire cold storage management to enable them to maintain product quality. However, there may be some challenges that may hinder compliance and that is what this study seeks to address.

\subsubsection{Profitability}

Profitability is known to be financial gains attained by a firm as a result of its productive activities. This section explains the variables used in this study.

\section{Variable}

This study used three variables, one independent variable, and two dependent variables. Facility management regulatory standards as an independent variable, quality, and profitability as independent variables. This is because quality may be enhanced when there is full compliance with standards. Whiles product quality helps to increase sales thereby affecting the profit.

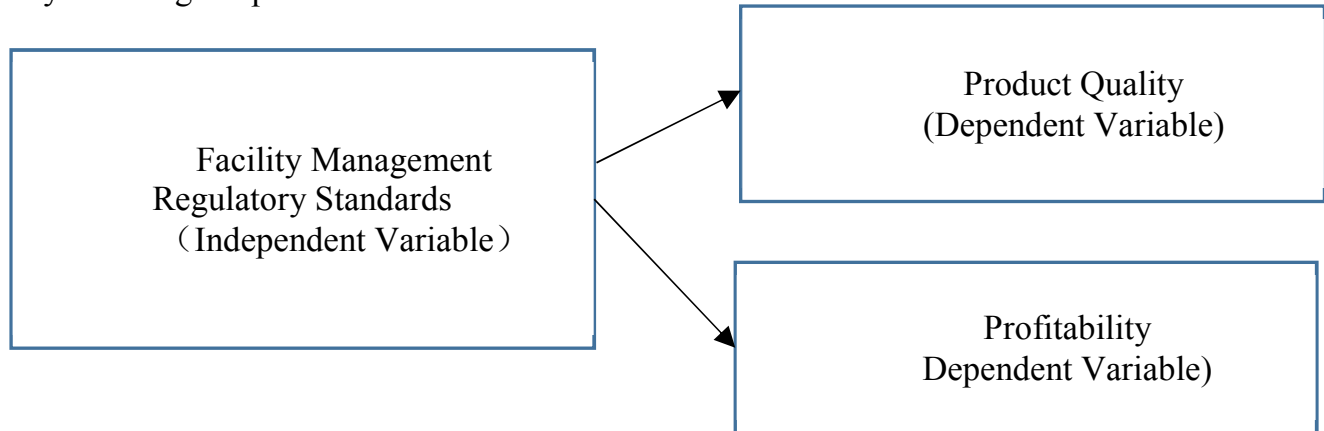

Figure 2.1.3 Variables Model- Constructed by Researcher (June 2021)

Generally, there are many found factors that determine profit, namely price, quantity, variable cost, and fixed cost, and others. Price; firms have to ensure that the prices of products cover their cost and also fall within the current market rate in order to stay competitive. Quantity; is the numbers or volumes the firms can sell. Variable Costs; such as labor and materials and Fixed cost; such as rent, plants, and machinery all adds up to cost. These factors can have either a positive or negative impact on the firms' profit. (Wu, M., Gao, X., \& Wieczorek, R. Bob, 2019) ${ }^{[12]}$. However, it can be argued that quantity (high volumes of sales) can come based on two factors. (i) That the Product is of good quality or (ii) that the product is of low quality due to deterioration. Depending on the choice of the customers, there can be high sales in each of these conditions. However, the former leads to profit, and the other leads either break-even or low profit. This also applies to cold storage operations. It is clear that there can be extra cost involved in adhering to regulatory standards and becomes part of the cost which is in determining price. This raises the prices but due to the product quality customers will still purchase and be loyal to the firm. Meaning that though the price of the product is high, there will still be high sales volumes (quantity) which leads to 
profitability. On the other hand, firms that do not follow regulatory standards may get their products deteriorated at some point may be due to low power supply or sudden breakdown of machines. The best option in that situation will be for the firm to reduce the price of the product to sell. It is obvious that there could be sales in high volumes (quantity) because definitely, some customers may consider price over quality but the implication is that the product can be seized and destroyed by the regulators should they get to know. This may reduce the firms' profit since the prices sold at that time may be below the market price and in addition, pay some penalties which may destroy the firms' reputation. This shows that in relation to cold storage operations, the quality which results from adhering to regulatory standards may be considered as determinate of profit. Meaning that the better the quality the more can be sold at the actual market price. Therefore, firms strive to look for increased sales and at the same time trying to reduce the storage-related cost to increase sales and maximize profit. As such they may frown on any action that may hinder them from achieving this objective (Espinosa, A., \& Kadić-Maglajlić, S. 2014) ${ }^{[13]}$ it is obvious that they will feel reluctant to comply due to the high compliance fee involved and realizing that there is no monetary value in. ISO (International Standard Organisation) $41001 ; 2018(\mathrm{en})^{[14]}$ outlined some of the benefits which were, improved and healthy workforce, improved efficiency and effectiveness which helps to improve cost benefits, and improved service quality and consistency. In relation to cold storage management, adhering to facility management regulatory standards is key to such an operation especially in the preservation of frozen products to maintain high quality which aids in selling or distributing at the existing market price. In other words, low quality means the low price which goes contrary to the objectives of the business (i.e. maximization of profit).

1. Assumption

It can be assumed that technology management systems, etc., in general, contribute to the changes in profits. However, these factors have not changed so much in cold storages operations. Meaning that the effects of their changes or the effect of other factors do not create so much an impact on profit but the main change is the use of standards. Here the profit change could increase or decrease as a result of standards, so there exists a strong relationship, and compliance to these standards enhances product quality which leads to higher sales. This means that the better the quality the higher the sales at any reasonable market price but not cheap. And quality can be attained when firms holistically adhere to regulatory standards.

\subsection{Review of Cold Storage Management Regulatory Standards on Firms' Profit}

Cold storage facility management comes in the cold chain and helps to ensure that the product is kept safe for export or consumption in the country.

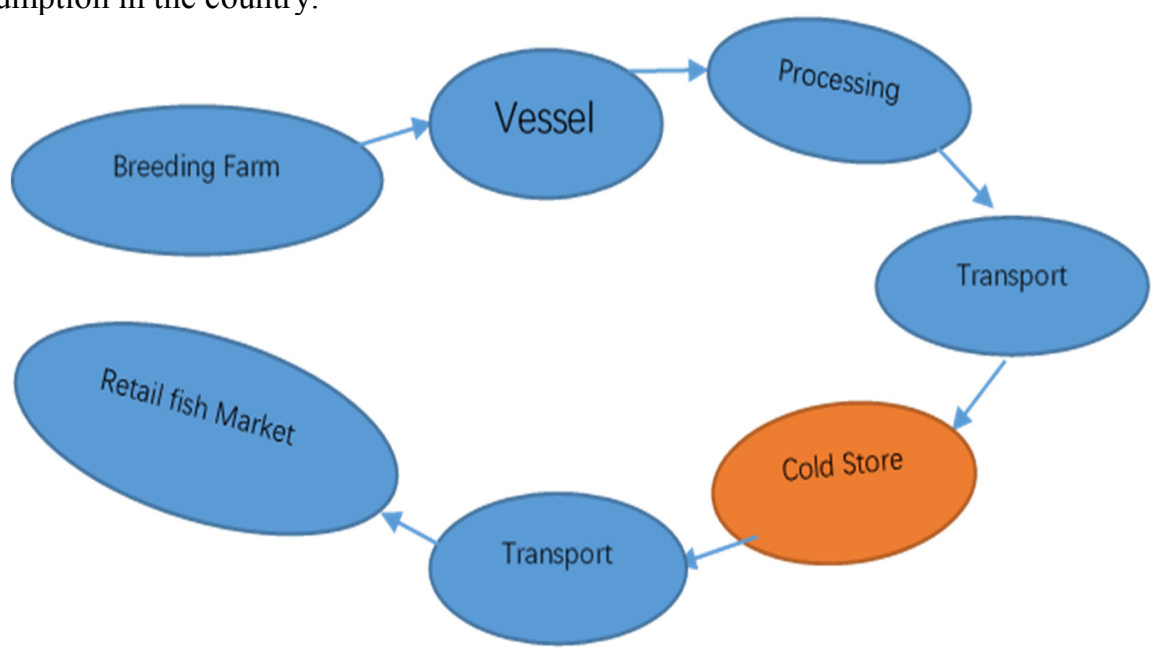

Figure 2.2 Cold Chain Flow; Constructed by Researcher (June 2021)

At every stage, as shown in Figure 2.2, there is the need to maintain the right temperature at -18 Degree Celsius or less. This is quite a challenge because of the need to always maintain a required temperature of -18 degrees Celsius or less for the purpose of storage and at the same time trying to keep the equipment and the staff warm to enable them to operate efficiently and effectively. According to (IIR, 2003); cooling products and keeping them at low temperatures costs more in hot climates than in temperate zones. (Kenny, G. P., Flouris, A. D., Yagouti, A., \& Notley, S. R. 2018). ${ }^{[15]}$ This means operations in countries like Ghana may attract huge electricity bills, as well as fuel costs when power is off. Meaning, there should be well-functioning equipment to be able to keep the required temperature. It is obvious that additional regulatory requirements, such as the provision of PPEs to staff, medical examinations, and registration fees may be seen as additions to operating costs that may affect the profit of the business either negatively or positively. In addition to the regulations, the firms must also have their clear procedures in place as management's effort to follow the required standards known as Standard Operating Procedure (SOPs) to protect temperature-sensitive products (Standard Operating Procedure. Definitions, 2020)[16] 
This means that firms should have a clearly stated requirement written in simple English and following the foodgrade inspection processes which are precise and easy to be understood.

However, according to research done in Isparta, Turkey which made a comparison of the normal and controlled atmosphere of cold storage facilities in terms of investment costs and profitability, it found out that, in comparing benefit-cost ratio in terms of normal (where normal means, there are no strict rules) and controlled

(where controlled means, there are strict rules to have adhered to ) atmospheres, the result was 1.03 for normal and 1.39 for controlled atmospheres which economically proved that controlled atmosphere is more advantageous than the normal atmosphere cold storages. (Calvert, J. G. (2016). ${ }^{[17]}$ Meaning that when good practices are holistically adhered to there will be profitability in the long run, however, when the standards are rigid it may result in a negative impact as already stated above. In addition, Porter, M., \& van der Linde, C. $(1995)^{[18]}$, a hypothesis developed concluded that greater regulatory stringency leads to greater profitability, and in contrast, the conventional costly regulatory stringency weakens profitability. In other words, a higher cost of compliance may dwindle the firms' profit.

After twenty years in a review discussion on the Porter Hypothesis twenty, it was found that regulatory standards aids in product quality however, extreme standards and strictness prevents firms from thinking innovative and which in the long run reduces firms' profit. (Murthy, U. 2020) ${ }^{[19]}$.

Sakrabani, P. (2020) ${ }^{[20]}$., in "Propagation of risks and their impact on performance in fresh food retail", The International Journal of Logistics Management had research and the purpose of the research was to carry out structural analysis of potential supply chain risk and performance measures in fresh foods retail by applying the Interpretive Structure Modeling (ISM). The finding was that in using the ISM approach the risks and performance measure the result was clustered according to the driving power and dependence power. It went further to detail that change in or inadequate government regulations at the bottom level of the hierarchy implied the highest driving power and required higher focused mitigation strategies. However, risks like lack of traceability, transport delays, and breakdown temperature abuse, cross-contamination in transport or handling and storage had medium driver and dependence powers though the work was deemed to be the first to link supply chain risk to performance, it failed to discuss the impact of the risk on the firm's profit.

\subsection{Review of Foreign Research on cold storage operations}

This section looks at the various foreign studies on cold storage operations.

1. Global Review

Cold storage capacity globally according to a report on Global Cold Storage Capacity produced by Global Cold Chain Alliance stated that the cold storage capacity has reached 616 million cubic meters in 2018 showing an increase of $2.67 \%$ since 2016 with the United States having a total capacity of 131 million cubic meters in 2018 whiles India moves ahead with a difference of 150 million cubic meters. This shows that globally cold storage firms are contributing a lot to the preservation of frozen products for safe consumption.

\section{Sub-Saharan Africa}

However, an Agroindustry policy brief on developing the cold stores in the Agrifood sector in sub-Saharan Africa published by the Food and Agriculture Organisation of United Nations (FAO) and the international institute of refrigeration (IIR) based on a workshop held in Cameroon in June 2012 which analyzed the various findings from case studies conducted in food supply chains that included meat, fruits, vegetable fish, seafood, milk, and dairy products. (Mwacalimba, K. 2016) ${ }^{[21]}$. The significance of the problem was lack of reliable and adequate cold chain facilities in sub-Saharan Africa was found to be the main cause of losses of perishable products which are estimated to be about 25-30 percent for animal products. This result they concluded does not only result in deterioration losses of food security but also market opportunities. One of the causes of these losses was found to be weak organization and implementation of controls for compliance with standards and weak organizational arrangements for value chain activities. These according to them lead to limitations in marketing opportunities, reduce the accessibility of products to consumers leading to reduced profits which are related to this study. The recommendation under governance was that government must clearly define quality regulations and standards, particularly in relation to food safety and environmental sustainability. Also, monitor the application of standards and regulations through effective compliance control. Meaning that the specific roles of the regulatory Authorities must be clearly defined and properly disseminated to the firms to avoid duplications of roles and finally eliminate misinformation. (Draper, R., 2017). ${ }^{[22]}$ For the Cold storage facility management, it was stated that there should be proper maintenance and staff training to reduce the risk of losses and injuries.

\section{United States of America}

The cold storage market in the United States in 2018 analysis report on processed food, fish, meat, and seafood, it was stated that the cold storage market was expected to reach 19.69 billion dollars by 2025 which will represent $3.7 \%$. This was regarded as one of the leading markets which use developing technology for effective management of cold stores and well-structured standards. It was also noted that of the products where high quality, advanced technology, and monitory system were considered as important, deterioration of frozen foods is reduced, it was 
found that the increase in the high growth was influenced by the high demand of frozen foods worldwide, however, it also stated that the high tariffs imposed on foods especially on imports resulted in a negative impact on the cold storage market. Valbuena, D. C., et al., (2020). ${ }^{[23]}$

\subsubsection{Cold Storage Management Regulatory Standards on Firms’ Profit}

According to a Market Analysis Report, the Global cold storage market size was valued at 107.18Billion USD in 2020 and has been expected to expand at a compound annual growth rate of $13.5 \%$ from 2021 to 2028 . It is of the view that the market has benefitted significantly from the stringent regulations governing the production and supply of frozen products. This data indicates that there was significant growth in the cold storage market in North America from 2017 to 2018 and even expected that there will be further expansion and growth in the years to come.
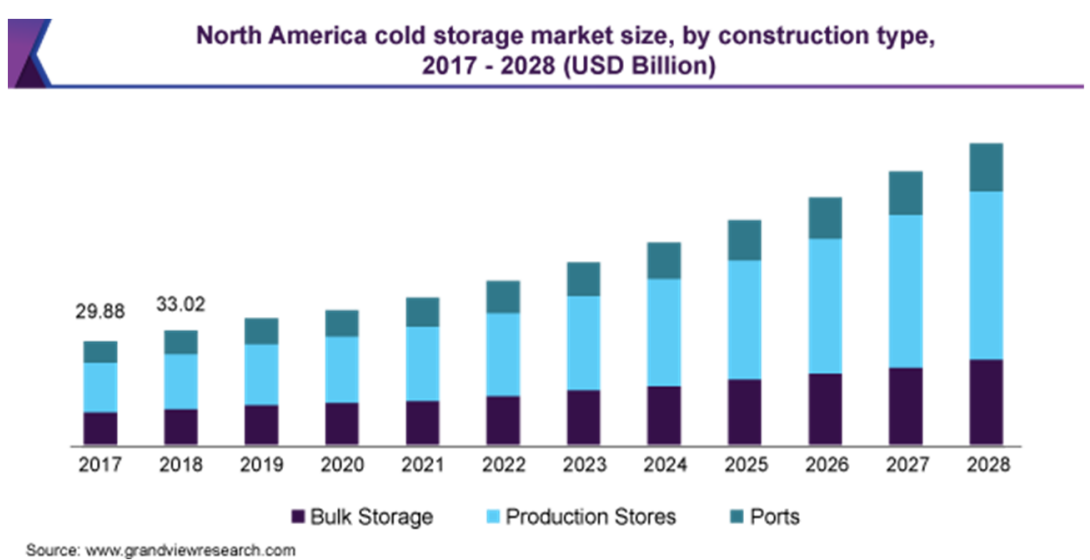

It was also of the view that fish and seafood led the market and accounted for over $35 \%$ share of the global revenue in 2020. This indicates that cold storage operations become lucrative when the standards governing the deterioration of frozen foods need to be adhered to holistically.

Global cold storage market share, by application, 2020 (\%)

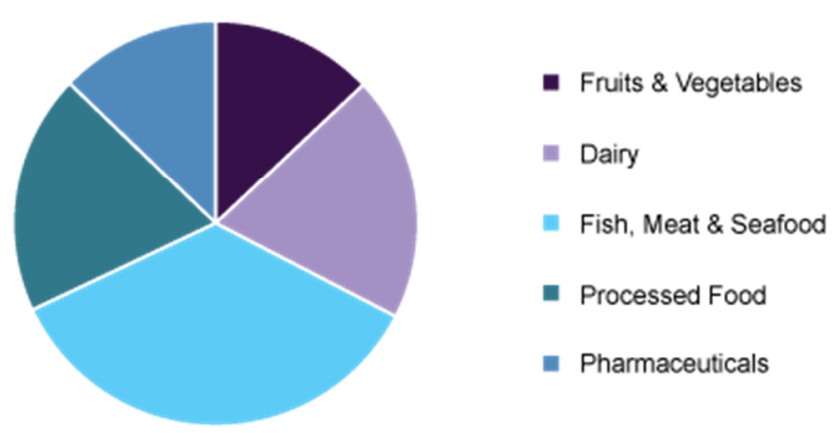

Source: wwx.grandviewresearch com

It is obvious that new technology can help the overall construction period, and reduce cost set up cost, operations, and maintenance but paying attention to the required standards cannot be compromised. However, the industry is faced with some challenges such as lack of infrastructure, lack of power, etc. but it is with the view that such challenges will open growth avenues for innovating unique solutions to overcome them. (https://www.grandviewresearch.com/industry-analysis/cold-storage-market) ${ }^{[24]}$

\subsection{Review of Domestic Research}

Ghana is a country located around the Gulf of Guinea. Due to this, most of the people found in the southern and central parts of the country engage in fishing. Cold storage (i.e. an essential system for extending the life of a frozen product and helps to maintain product quality) operations then steadily increased when the fishermen found the need to store excess fish rather than other traditional ways of preservation such as salting, drying, smoking, and drying. Some of these fish are kept in cold stores whiles others are exported. This caught the interest of some individuals to invest in cold storage operations. The regulatory authorities in proving consumers with quality products have gained much attention in especially in this pandemic era have put in place strict policies to ensure customer satisfaction, whiles the firms are more concerned with profit maximization. (Mandy, D. M. 2017) ${ }^{[25]}$. However, products such as fish get rotten due to defective cold storage facilities which result in huge losses when 
not kept well. It is of the view that one of the disturbing issues with firms, in general, is the lack and poor maintenance culture of facilities. (Chiekezie, O. M. 2017) ${ }^{[26]}$. Although the government for the past years has and is still doing its best to curtail the menace, the situation still persists. According to an interview granted, fishermen revealed that the defectiveness of the products might be due to the heavy indebtedness of firms to pay bills since its often postpaid, such as electricity bills which results in power disconnections. (Scadden, J. 2019) [27] it is obvious, that the government has put various measures such as laws and policies in place to ensure product quality, hence the need to adhere to those measures. (Scadden, J. 2019) ${ }^{[28] . ~[29] ~ R o s e, ~ R . ~(2017), ~}{ }^{[30]}$ in his research on assessing sustainable practices in facilities management, it can be said that sustainable principles that are practiced with regard to facility management which cannot be said about practices are entirely unsustainable due to a lack of knowledge of the concept and client influence on decision -making. Cold storage management regulatory standards on firms' profit. The issues of cost of compliance have been established fact and which the cost of non -compliance is mostly measured by penalties and fines which sometimes the extreme becomes business closure. Those who oppose the pressure of compliance with the regulatory standards argue that the regulations only expand bureaucracy adding more burden to the operators in the industry. (Amin, M. K., \& Zaman, M. 2020) ${ }^{[31]}$.

Compliance therefore may result according to the regulators in a positive effect or impact on the quality of the product. In other words, the result of compliances can have direct economic value. On the other side, though didn't find any work to prove this statement, it is obvious and becomes very difficult to dispute that regulators tend to raise quality high to either benefit or protect consumers. There are some who also argue that self-regulation is the best control as it imposes the minimum amount of cost on the form and the regulator. However, there is also a shift that acknowledges if there exist a globally working communication infrastructure, internet and other sources of communication, or a collaborative platform for both regulators to work together across organizational boundaries. Meaning that if the appropriate regulation tools and processes are used operators will enjoy the benefits of minimized cost of compliance, which will result in profit maximization and increased effectiveness.

\subsection{Cold Storage Management Regulatory Standards and its Effects on Firm's Profit 3.1 Introduction of Cold Storage Facility Management regulatory standards}

Facility Management (FM) is concerned with the management, operation, and maintenance of a firm's facility, balanced and rapid changes as well as effective monitoring and control to meet the needs and demands of the stakeholders with the effective, safe and sustainable product or service (Nävy, J., 2018) [32]. It is also required that firms engaged in cold storage operations will adhere to regulatory standards in order to achieve this goal. In view of that, the government of Ghana through the legislative instruments instituted various authorities and agencies to ensure that the objective which is providing the citizens with safe and sustainable products or services is achieved through effective monitoring and control. the framework below shows the legal and legislative framework of the cold storage operations in Ghana which was created from the various acts of the respective institutions.

\subsubsection{Ghana Standards Authority (GSA)}

The Ghana Standard Authority- (GSA) established in August 1969 is solely responsible for the nation's quality infrastructure embracing three-pillar neurology standardization and conformity assessment (that is test inspection and certification). The quality infrastructure is based on the fact that a sound quality infrastructure provides the necessary assurance, that goods and services are the acceptance quality, again promoting the growth of industry enhances sustainable development and contributes to good public governance. They are, therefore, mandated to undertake testing services, inspection activities, product certification schemes. Calibration, verification, and inspection of weight, measures, and weighing and measuring instruments. Pattern approval of new weighing and measuring instrument. Destination inspection of imported high-risk goods, promoting quality management systems in the industry. The activities of the GSA are essential for economic growth and are based on Food and Drugs Authority. Also, conformity to the standards helps reassure consumers that products are safe, efficient, and good for the environment. the benefits are deemed to benefit those who comply in areas such as cost-saving, enhanced satisfaction, access to new markets, increased market share, and environmental benefits. They operate under the GS929 code of Hygienic Practices, GS239 code of Requirement for established systems, and GS 1131 code of Practice for the reduction of polycyclic aromatic hydrocarbons. Ghana standards, therefore, do not monitor and control the cold store firms in general but only those registered with them and are involved in the exportation of fish and other frozen products since they are to meet the required international standards. However, in the cause of discharging their duties, they do well to correct any negative activity.

\subsubsection{The Department of Factories Inspectorate}

The department was established in accordance with carrying out the provisions of the factories Act of 1970, act 328 according to section 74(i) of the factories act, and responsible for enforcement of factories, offices and shops Act (Act 328, of 1970) which was amended in 1983 to conduct a technical health, safety, and welfare inspection regularly of all premises with jurisdiction to ascertain compliance of the law. It is obvious that workplace health and safety are vital especially in cold storage operations. This is due to the fact that accidents or workplace injuries 
affect not only the personnel but the firms and society as a whole. In this view, it becomes needful for wellestablished legislation which helps to ensure the health and safety of the personnel to prevent infections and contamination of the product, especially during this pandemic. They ensure that both new and existing factories and shops are all registered. Their main responsibilities are health and welfare assurance Cleanliness, protective clothing, medical issues, etc.) as well as keeping all operations are free from dangerous conditions and practices. However, research conducted found that the role of the department of factories inspectorate was poor, ineffective, and infrequent due to lack of resources such as staff and budgetary support. (Appiah, Samson O., 2013) [33] [34]. In relating to cold storage operations their roles are to ensure that all the firms adhere to the regulatory standards. Such as maintaining the right temperature to ensure the product is wholesome for public consumption, the safety of personnel in terms of health, provision of PPEs (Personal Protective Equipment and all other safety measures in the premises of the firms. One can then assume that their role is similar to that of TMA and Port Health since they are all responsible for the product quality, health, and safety of both workers and customers.

\subsubsection{Food and Drugs Authority (FDA)}

According to the Food and Drugs Authority's (FDA) code of practice for cold storage facilities (2013), it stipulates that, in exercising the powers conferred on the authority by the Public Act, 2012, Act 851, Part seven, section 148, subsection( $2 \mathrm{~g})$, code practice applies to the cold storage of meat and fish in order to ensure their safety and quality and this code of practice is intended to help the cold storage facility operators comply with the requirements of the FDA in order to maintain their integrity for their intended purpose.

\subsubsection{The Environmental Protection Agency -EPA}

This institution operates under EPA act 1994 (490) enacted on 31st December 1994, LI 1652 and It is an implementation agency, a regulatory body, and services as a catalyst for change towards sound environmental stewardship. Their mission is to co-manage, protect and enhance Ghana's environment in particular as well as seek solutions to global environmental problems. Their role in Cold storage facility management is to ensure that, there is minimum environmental and air pollution in the course of firms' operation. Meaning that they deal with highly technical issues and documentations and their roles have no connection with the quality of fish or other frozen products. They ensure that the facility is well structured and positioned without interfering with the drainage systems, and the activities of the firms do not emit any form of nuisance (noise and fumes from machines and equipment, spill of Freon, or ammonia) that will affect the environment and the people around. In other words, the outfit deals with more technical issues concerning environmental pollution and therefore does not directly control and monitor Cold storage operations. EPA Act 2019, LI 2386 outlines the reviewed registration fee for all businesses and it is renewable every 18 months.

\subsubsection{The Port Health/TMA}

Port Health is a unit under Ghana Health Services precisely the Public Health Directorate and operates under international Health Regulations (IHR), 2005, which was developed by the World Health Organisation (WHO) to help countries to develop the spread of public health risk. Relating to cold storage under section 8 of their ByLaws CAP 78, 908 amended in 1935 and still in operation mandates them to ensure products that leave the port and cold storage facilities are safe for human consumption. Port Health is also concerned with the Food handlers and Food processors within the Ports of the nation especially the importers. The Tema Metropolitan Assembly (TMA) plays the same role but is concerned about the operators in generals within municipal. In addition, they are responsible for issuing Business Operating Certificates to enable the businesses to operate. There is the need to register with any of them since their main concern is how the environment in which the firms operate is kept. For example, waste disposal, pipe water, washrooms, and dressing rooms for the staff. Each requires a fee and is renewable annually.

\subsection{Management system of Cold Storage Facility Management regulatory standards}

The purpose of this framework describes the management system of cold storage facility management regulatory standards and was constructed based on the legal and institutional framework that provides the functions and roles of the various regulators. mandates of the various regulatory institutions including Fisheries L.I. 2002; Act 625. The fisheries industry in Ghana is regulated by the government through the Ministry of Food and Agriculture, Ministry of Fisheries and aquaculture, and the fisheries commission to help sustain the fisheries management these sectors concentrate more on the marine section rather than cold storage operations. However, they monitor the firms that have fishing trolleys and are licensed to fish on Ghana waters to ensure that, the right method is used in the process and therefore are not directly related to cold storage operations. (Appiah, Samson O. 2018). [35] According to Nävy, J. (2018) ${ }^{[36]}$, a firm's actions may affect the health and well-being of all customers they deal with and therefore involves occupancy cost, security, maintenance, and environmental cleanliness. In Ghana, there are several regulatory Authorities, namely Food and Drugs Authority (FDA), Ghana Standards Authority (GSA) and Environmental Protection Agency (EPA), and The Port Health (with the Port) or Tema Metropolitan Assembly-TMA (outside the Port) depending on your location and Factories Inspectorate. However, most of the regulations for Cold Storage Facilities Management are enacted, monitored, and controlled by the FDA whiles the 
others (GSA, EPA, and Port Health or TMA and Factories Inspectorate) ensure adherence. However, each of them is autonomous according to their mandates. It is mandatory or required that every firm registers with these regulatory bodies and they exist to ensure one thing that is, ensuring firms are keeping products safe for human consumption. Meaning that these regulators together with the firms are supposed to work in collaboration. Looking at the arrows, clearly shows that there is forward and backward communication between all the stakeholders. That is, The Factories Inspectorate upon seeing anything unwholesome may report to the respective authority responsible for instance, Food and Drugs Authority likewise the others. It can be said that the regulators can be more effective in their control and monitoring when there is strong collaboration.

The management system of Cold Storage Facility Management regulatory standards

Ministry of Food and Agriculture

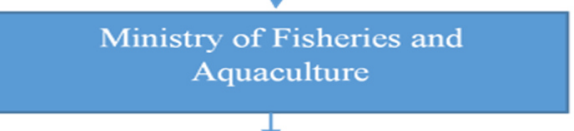

Fisheries Commission

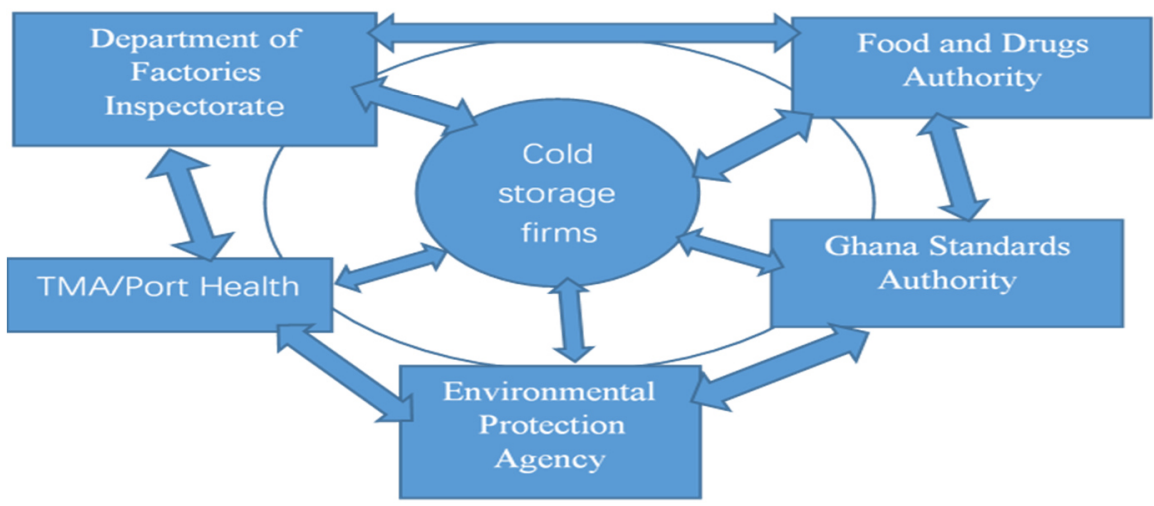

System based on Fisheries L.I. 2002; Act 625 and stipulated mandates of the regulators: Constructed by Researcher: June 2021

\subsection{The Impact of Cold Storage Management Regulatory Standards on Firms' Profit}

The issues of cost of compliance have been established fact and which the cost of non -compliance is mostly measured by penalties and fines which sometimes the extreme becomes business closure. Those who oppose the pressure of compliance with the regulatory standards argue that the regulations only expand bureaucracy adding more burden to the operators in the industry. Compliance therefore may result according to the regulators in a positive effect or impact on the quality of the product. In other words, the result of compliances can have direct economic value. On the other side, though didn't find any work to prove this statement, it is obvious and becomes very difficult to dispute that regulators tend to raise quality high to either benefit or protect consumers. There are some who also argue that self-regulation is the best control as it imposes the minimum amount of cost on the form and the regulator. However, there is also a shift that acknowledges if there exist a globally working communication infrastructure, internet and other sources of communication, or a collaborative platform for both regulators to work together across organizational boundaries. Meaning that if the appropriate regulation tools and processes are used operators will enjoy the benefits of minimized cost of compliance, which will result in profit maximization and increased effectiveness. Profitability is very crucial in firms' financial performance and some studies have contributed to knowledge in this aspect in other fields such as Pharmaceutical. D. Klassen, Curtis P. McLaughlin ${ }^{[37]}$ in their article published in 1996 "The Impact of Environmental Management on Firm Performance" stated that environmental management has the potential to play a pivotal role in the financial performance of the firm. Many individuals suggest that profitability is hurt by the higher production costs of environmental management activities, while others cited anecdotal evidence of increased profitability. Regulatory compliance by enterprises could result in a positive or negative effect on profit depending on the cost involved in compliance and other areas of operations. Lundgren et al., (2017) ${ }^{[38]}$ found in their work that there is a positive significant effect between managerial aspect on firms' performance and profitability when they analyzed the interrelation between the firms' performance, productivity, energy efficiency, and environmental performance. This means that managerial decisions and actions may have an effect on the firms' profitability. There is also the view that the correlation between productivity and financial performance which helps to achieve an annual increase in profitability value over the productive life of a firm is considered to be very important in determining present and future policies and therefore firms do their best to avoid the extra or uncalculated cost that may come from laws or restrictions. (Widarwati, E., \& Sartika, D. 
2018). [39]

\subsection{DATA ANALYSIS AND PRESENTATION OF RESULTS}

The chapter presented the data collected from the field through an interview/questionnaire and analyzed it to excerpt the findings of the study. The presentation was based on the previously outlined objectives of the study.

The study employed descriptive analysis (frequency with percentage and mean score with standard deviation) for the quantitative data and content analysis for the qualitative responses. The study sample was categorized into four stakeholders; (owner/managers) of cold storage operations, customers of cold storage operations, and regulators; - heads of departments, and field inspectorate. The total sample size achieved for each category were respectively 15, 45, and 9 totaling 69 out 72 respondents. The study, therefore, achieved an 86.3 percent response rate which is significantly high. Although the response rate was high, customers and managers had the highest return rate of $100 \%$ each while regulators recorded a 75 percent response rate.

\subsection{Report on Managers Data}

\subsubsection{Demographic Characteristics of the Managers}

The first section of the interview/questionnaire of the managers sought to establish the demographic characteristics of the managers (respondents), namely; age group, position, gender, educational level, and whether the firm registered or not. The results presented in Table 1, the age bracket of the managers was made up of mainly 31-40 years and above 40 years, representing 10.0 percent and 46.7 percent respectively. The age brackets revealed the respondents were in their active service and are effective enough to provide information on cold storage regulatory standards questions to foster the assessment of the impact of facility management regulatory standards on firms' profit. The managers were made up of CEO/founders, managing directors, and managers, representing 20 percent each for /founders and managing directors and 40 percent for managers. The gender distribution of the managers in the study was made up of 66.7 percent male and 33.3 percent female. This result suggested the management position of the cold storage operation is dominated by the male gender. It was observed that the majority of the managers had their educational level to be tertiary, represented by 80.0 percent, while the remaining were secondary school graduates. The high educational level of the manager will go a long way to contribute to the broad achievement of the objective of the study. The cold storage facility was mainly owned by the firms representing 66.7 percent, about 20 percent were rented and 13.3 percent were owned by the state.

Table 4.2.1: Demographic Characteristics

\begin{tabular}{|c|c|c|}
\hline & $\mathbf{N}$ & Percent \\
\hline \multicolumn{3}{|l|}{ AGE } \\
\hline 20-30 years & 2 & 13.3 \\
\hline $31-40$ years & 6 & 40.0 \\
\hline Above 40 years & 7 & 46.7 \\
\hline Total & 15 & 100.0 \\
\hline \multicolumn{3}{|l|}{ Position } \\
\hline CEO/Founder & 3 & 20.0 \\
\hline Managing director & 3 & 20.0 \\
\hline Manager & 6 & 40.0 \\
\hline Others & 3 & 20.0 \\
\hline Total & 15 & 100.0 \\
\hline \multicolumn{3}{|l|}{ Gender } \\
\hline Male & 10 & 66.7 \\
\hline Female & 5 & 33.3 \\
\hline Total & 15 & 100.0 \\
\hline \multicolumn{3}{|l|}{ Level of education } \\
\hline Tertiary & 12 & 80.0 \\
\hline Secondary & 3 & 20.0 \\
\hline Total & 15 & 100.0 \\
\hline \multicolumn{3}{|c|}{ Cold Storage Facility } \\
\hline State owned & 2 & 13.3 \\
\hline By firm & 10 & 66.7 \\
\hline Rented & 3 & 20.0 \\
\hline Total & 15 & 100.0 \\
\hline
\end{tabular}

Source: Field Study, 2021 
4.2.2 Various Standards on Cold Storage Facility Management and how Firms' are complying with the Regulatory Standards

This section of the analysis sought to establish the various standards of cold storage facility management and how firms are complying with the regulatory standards. The various measures considered were; the regulators in cold storage operations, the standards guiding the cold storage operations, and the extent to which the regulatory laws or policies support the effective delivery of work.

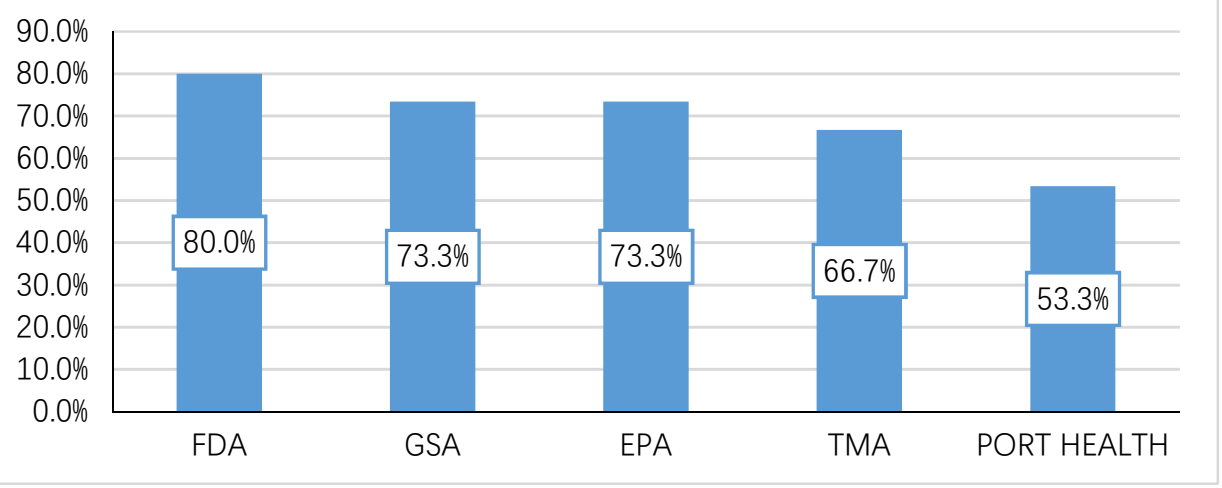

Figure 4.2.1: Regulators in Cold Storage Operations

The managers were asked to indicate the regulators of cold storage operations, all the regulators they know and the results presented in Figure 4.2.1 from the results, 80 percent of the managers mentioned FDA, 73.3 percent said GSA and also EPA, 66.7 percent TMA and 53.3 percent indicated Port Health. There were five regulatory bodies ensuring cold storage operators are operating within the regulatory standards of the state as indicated by the response.

1. The various standards guiding the cold storage operations

The study further asked the managers to provide the various standards of guiding the cold storage operations. The followings were the various standards guiding the cold storage operations according to the managers (Figure 4.2.2);

- Maintain a standard temperature for cold room

- Calibrate cold storage machines for good temperature

- Maintenance guidelines, personal protective equipment for cold-room workers

- Good health

- The floor of the cold storage

- A mandate by the authorities

- Clean environment

The above views from the managers (respondents) display depicted the provision of the cold of practice for the cold storage facility in Ghana.

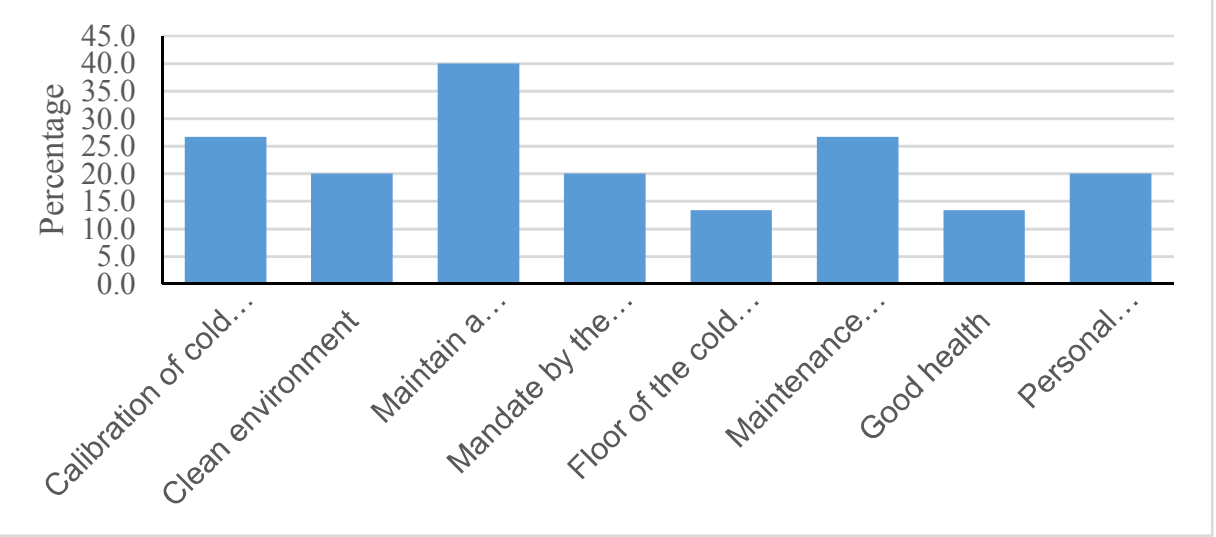

Figure 4.2.2: The various standards guiding the cold storage operations

Figure 4.2.2 provided the responses of the managers on the extent to which the regulatory laws or policies support the effective delivery of their work. From the results, the majority of the managers mentioned that maintaining hygienic and a safe working environment effectively supports their delivery of work. This provided them with wholesome products that serve customers well. It was added the SOPs help them to follow the maintenance, operations, and keep the place in order. Another extent for effective delivery of work as a result of regulatory laws or policies was the benefit of the firms and customers - when there is effective monitory. However, some of the managers described the regulatory laws or policies as a waste of time. The response was, "Most of the 
laws are totally a waste of time". The managers complimented they make sure that the regulators do the right thing.

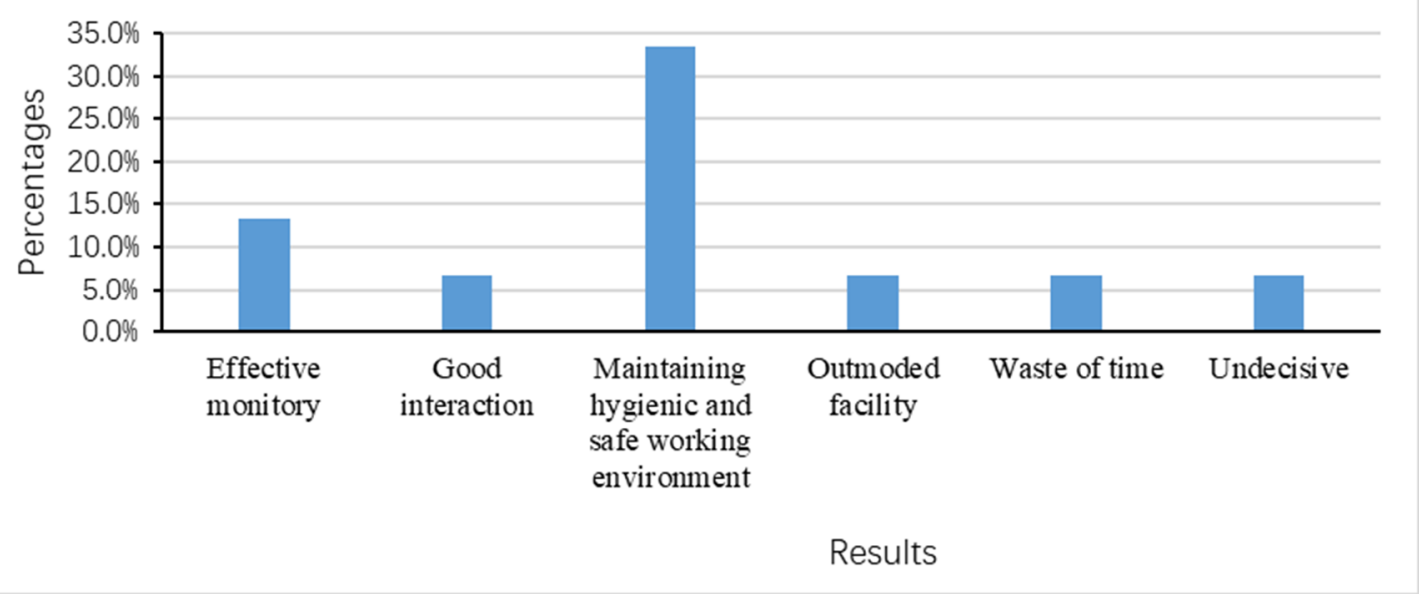

Figure 4.2.3: Extent Regulatory Laws or Policies Support the Effective Delivery of Work

\subsubsection{Challenges that Hinder Compliance with Regulatory Standards}

The managers were asked to provide other challenges aside from the well-known challenges faced by the cold storage operation; high cost of operations, unstable power supply, the effect of change in fuel prices. The followings were the additional challenges identified from the managers' responses (Figure 4.2.4); poor attitudes of workers, delay in document procurement, policy rate (exchange rate, interest rate, exorbitant property and ground rent), port and customs operations are time-consuming, high cost (of maintenance, plastic pallet, compliance fees, EPA license fees, medical certificate fees). Some of the managers indicated that there were too many regulators for cold storage operation and therefore must be reduced or integrated. Another challenge raised by some of the managers was regular training for cold room workers.

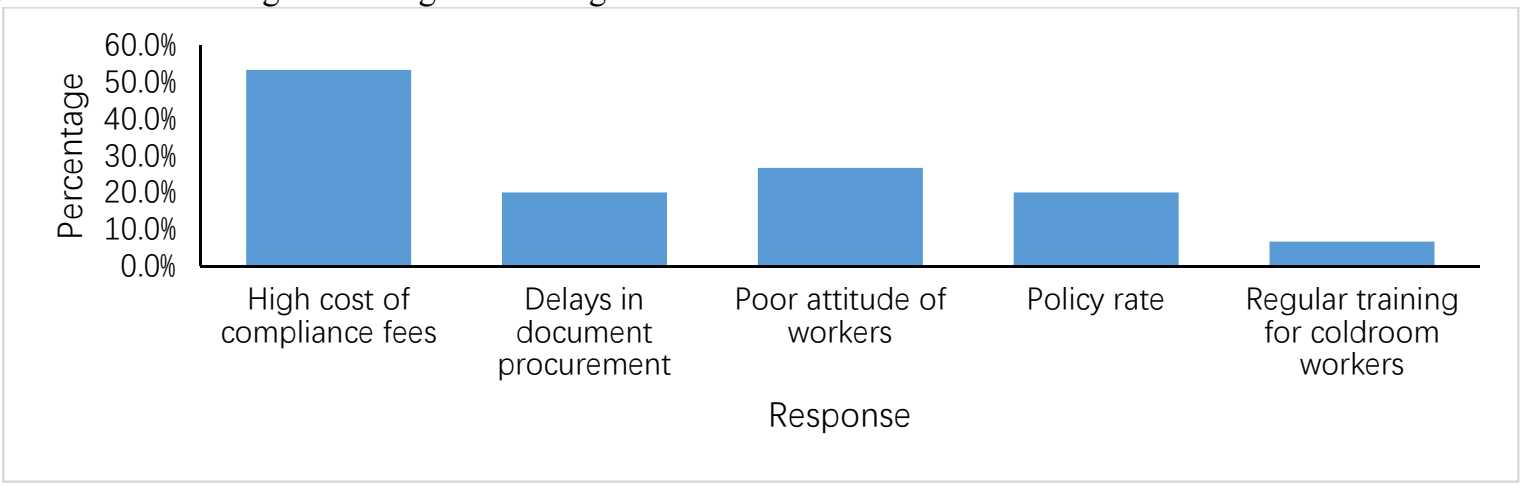

Figure 4.2.4: Other Challenges of Cold Storage Operations

1. Firms Reluctant to Comply with the Standard due to High Cost Involved

All the managers were of the view that firms are reluctant to comply with the standard due to the high cost of involvement. They collectively added that there are many regulators contributing to firms' reluctance to comply. There was also a failure on the side of the companies to register, indicated by about 13.3 percent of the managers. In addition to the problem of high cost causing firms to comply with standards reluctantly, lack of educative on the usefulness of maintaining unbroken cold stores led to non-compliance.

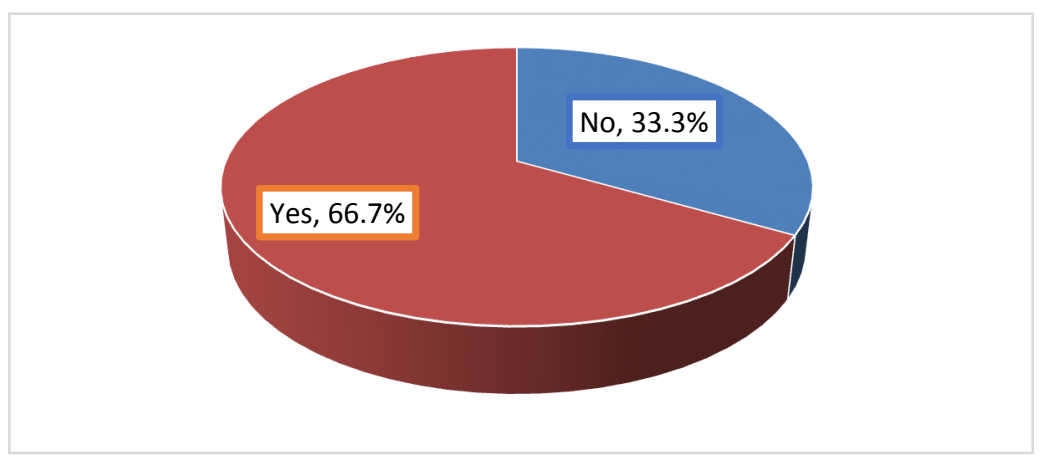

Figure 4.2.5: The roles of the regulators seem to be duplication of duties 
The majority of the managers indicated that the role of regulators seems to be a duplication of duties, representing 66.7 percent (Figure 4.2.5). These managers see the roles of EDA and EPA to overlap and that the cold storage operation needs not more than two regulatory agencies.

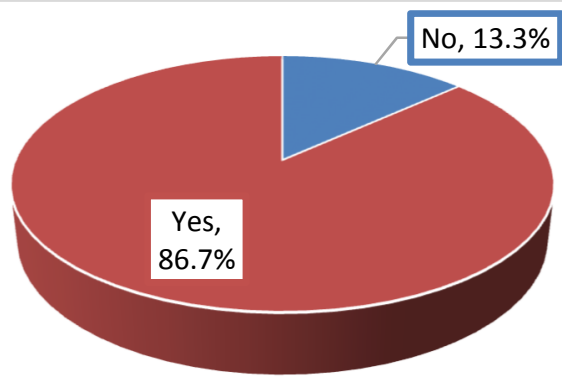

Figure 4.2.6: Current ways of managing cold storage facilities calls for change

The managers were asked to express their views on either the current ways of managing cold storage facilities calls for change. The responses showed a majority of the managers want the current ways of managing cold storage facilities to be changed, representing 86.7 percent. However, the remaining 13.3 percent did not think the current ways of managing cold storage facilities need to be changed (Figure 4.2.6). The respondents who indicated that the current ways of managing cold storage facilities need to be changed, further explained some of the regulators should be merged and the laws should be enforced (Figure 4.2.7). They reduce the energy consumption of the firms and solar panels should be used according to the managers. The cost of energy consumption from the national grip is too much for the firms' operation.

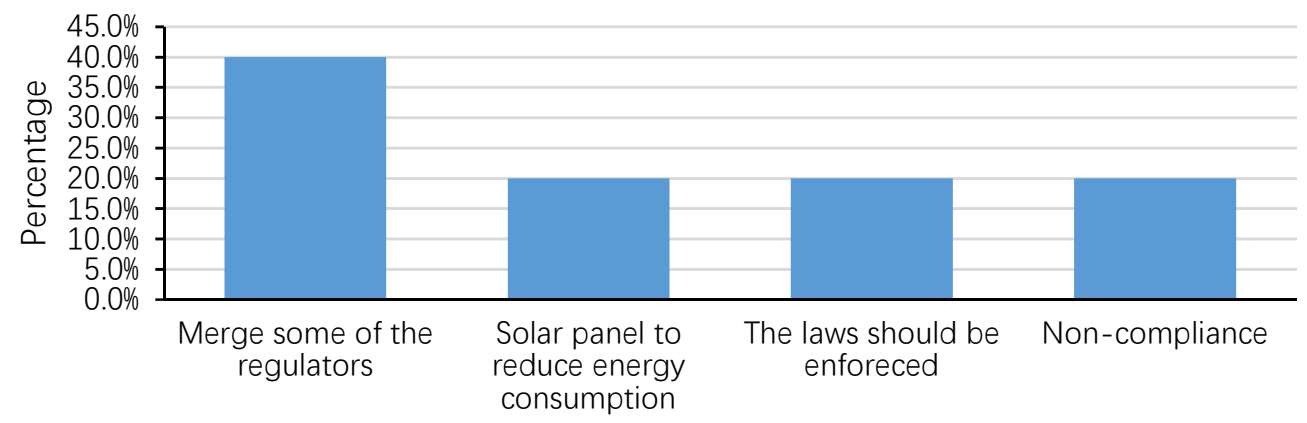

Response

Figure 4.2.7: Current ways of managing cold storage facilities calls for change

2. Innovative ideas employed to aid in reducing operational cost

The respondents outlined the following innovative ideas they have employed to aid in reducing operational cost

(Table 4.2.1);

- The use of solar panels to cut electricity

- Regular maintenance of foreign machines

- Proper management to prevent heat into the cold store

- Constant servicing of the freezer

- Merge the regulator for effective training of workers

- Compliance enhance innovation

The use of solar panels to cut electricity was mentioned by the majority (relative) of the managers. They outlined that, the innovation of changing machinery or regularly maintaining the foreign machines to avoid breaking down unexpectedly will increase operational costs. In maintaining the good temperature of the cold storage facility, proper maintenance to prevent heat into the cold store, use of electric facilities to reduce fuel consumption, etc. were employed to ensure the good temperature is achieved. 


\begin{tabular}{lcc}
\hline & N & Percent \\
\hline The use of solar panels to cut electricity & 4 & $28.6 \%$ \\
Regular maintenance of foreign machines & 2 & $14.3 \%$ \\
Poor management to prevent heat into the cold store & 3 & $21.4 \%$ \\
Constant servicing of the freezer & 2 & $14.3 \%$ \\
Merge the regulator for effective training of workers & 2 & $14.3 \%$ \\
Compliance enhance innovation & 1 & $7.1 \%$ \\
\hline Total & $\mathbf{1 4}$ & $\mathbf{1 0 0 . 0}$ \\
\hline
\end{tabular}

\subsubsection{Relationship between Compliance with Regulatory Standards and Profit Levels}

This section measures the views of the managers on the relationship between compliance with regulatory standards and the profit level of the firms. The opinions of these managers were sought on whether compliance enhances product quality, compliance has an impact on profit level, and whether there is a strong relationship exist between compliance with regulatory standards and the firms' profit. The results are presented below;

1. Compliance Enhances Product Quality

The managers collectively with exception of one agreed that compliance enhances product quality. They made comments to support the argument that safety protocol improves the products; hygienic and good appearance of fish products. Compliance also enhances productivity quality because the regulatory standard does not allow operators to sell bad products. This significantly enforce operators to adhere to a good standard and improve the quality of products. It was also made known that, compliance enhances productivity quality but full compliance is very expensive.

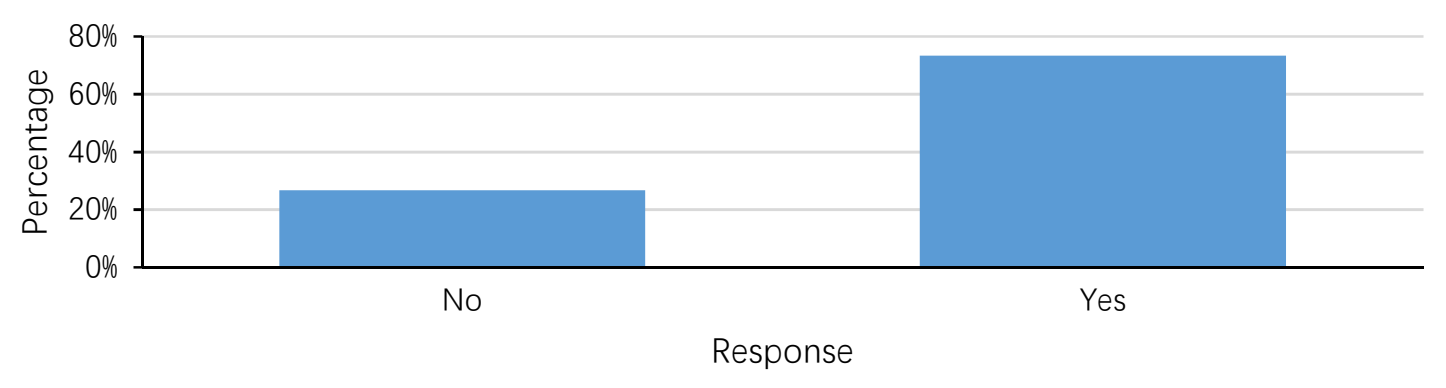

Figure 4.2.8: Compliance Impact on Firms' Profit

The managers were asked whether compliance has an impact on firms' profit. This was confirmed by 73 percent of the managers (Figure 4.2.8). From the view of the managers, compliance improved quality products which increase trust and increase sales, and therefore profit level affected positively.

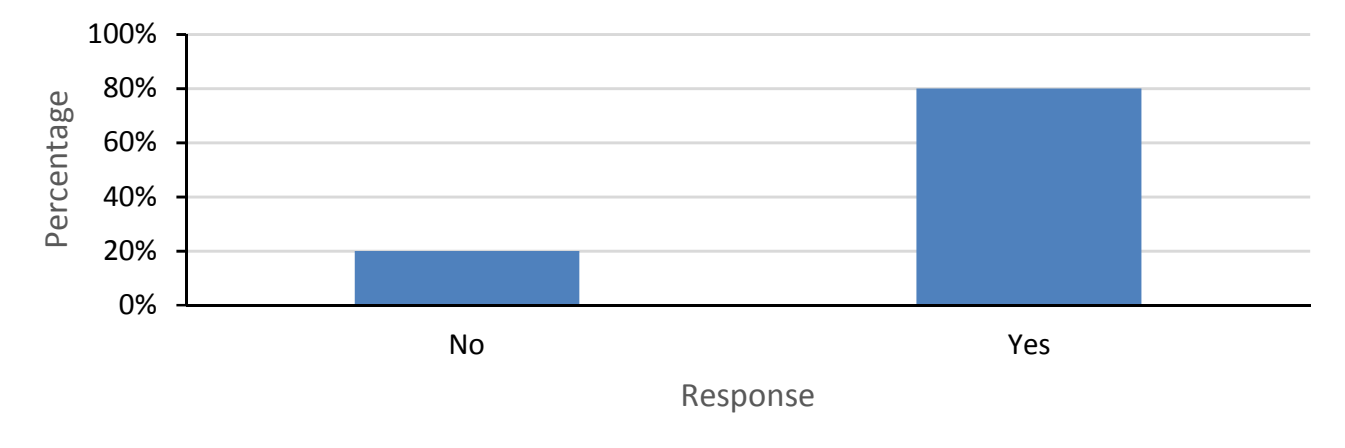

Figure 4.2.9: Relationship between Compliance and the Firms' Profit

The managers were asked to indicate whether there is a strong relationship between compliance with regulatory standards and the firm's profit. From (Figure 4.2.9), 80.0 percent of the managers agreed that there exists a strong relationship between compliance with regulatory standards and a firm's profit. However, the managers who disagreed that there is a strong relationship between compliance with regulatory standards and the firm's profit supported their argument that customers want cheap prices hence less quality.

\subsubsection{Recommendations from the Managers}

\section{Measures put in place to ensure full compliance}

Managers said firm operators should employ additional technicians to complement compliance efforts. They added adherence to standard operating procedures is key to ensuring full compliance. From the managers, apart from the standard requirement firms have to own their SOP to facilitate full compliance. There should also be safety officers available who will ensure compliance at all times. Task officers should also be used to ensure stewards adhere to 
SOP.

There should be balanced accidents that required monitory of temperature and observance of hygiene conditions. Ensure the right and regular temperatures are maintained, the product must be stored at the appropriate temperature, as well as the standard room temperature. Freezers must be serviced on time to avoid contamination. Firms comply to avoid penalties by monitoring. There should be the availability of PPEs, deployment of electric forklifts in the cold room rather than the device.

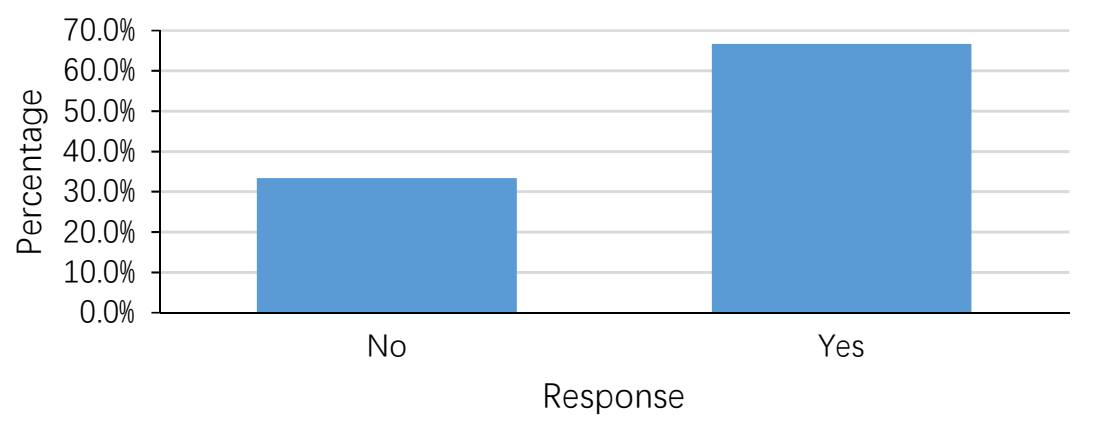

Figure 4.2.10: Think in order to save cost firms can employ a self-regulatory system for their operation

It was mentioned that the firms want to maintain the good qualification of product so they would employ a self-regulatory system for their operation. It was added that a required certificate is needed therefore self-employed regulatory system for the operation is needed. Other managers suggested collaboration with the regulatory bodies would be better. This is because the agencies are still needed even when self-regulatory is employed. Independent bodies should always ensure firms comply with regulations.

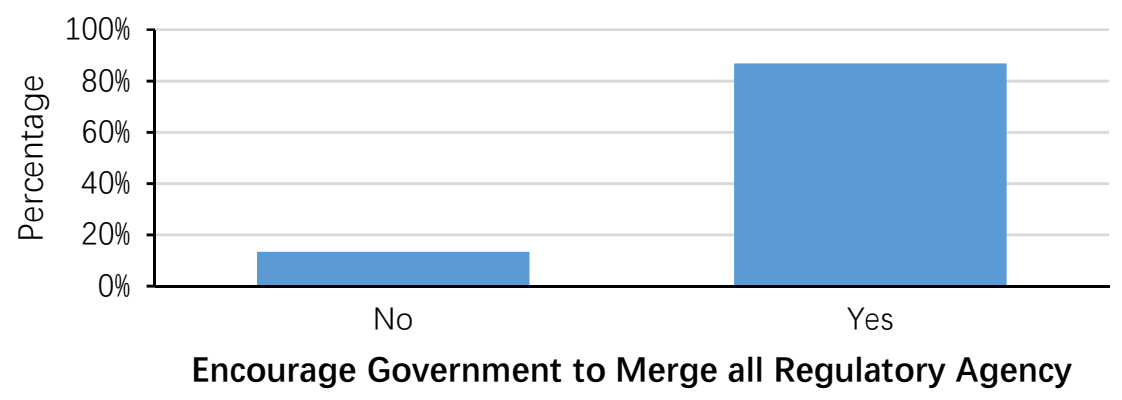

Figure 4.2.11: Encourage government to merge all regulatory agencies assigned to cold storage firms in one agency for the effective monitoring and operations

The managers' views were enquired, whether they would encourage the government to merge all regulatory agencies assigned to cold storage firms in one agency for effective monitoring and operations. The responses of the managers were in support of the assertion (Figure 4.2.11), that the government should merge all regulatory agencies assigned to cold storage firms in one agency for effective monitoring and operations. The followings were the reasons for the managers' views wanting the government to merge all regulatory agencies assigned to cold storage firms; "for effectiveness and ensure compliance", "that will be very effective and more compliance requirement easier", "there will be the positive impact if the regulators work holistic and treat everyone fair", "there should be shared and collaborated", "they should all be independent for effectively" (Figure 4.2.12).

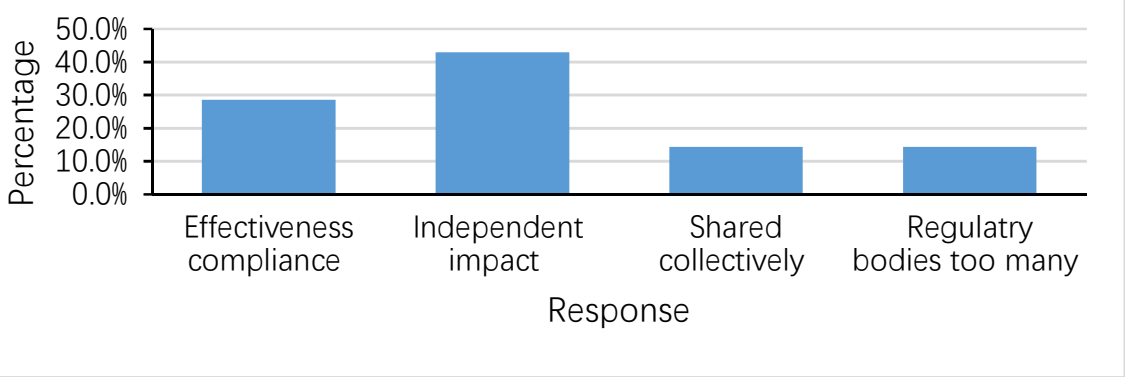

Figure 4.2.12: Encourage government to merge all regulatory agencies assigned to cold storage firms in one agency for the effective monitoring and operations 


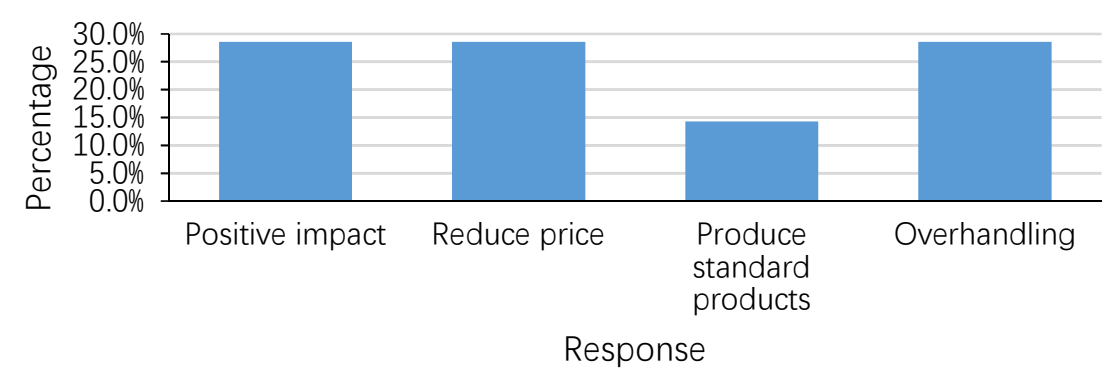

Figure 4.2.13: Other things to say about the impact of facility management regulatory standards on a firm's profit

The impacts of facility management regulatory standards on firms' profit according to the managers were that it reduced cost of employment, production of standard products, and system overhauling. The responses (Figure 4.2.13)of the managers were; "It is costly employing some of the standards, regulatory standards should be something lenient on the firm to gradually finance" and "The government should reduce the price"; "Regulatory standard has helped produced standard product"; "The need for system overhauling" and "There is a strong relationship of overburden"; "Some firms are not fit to operate in the cold store environment from a distance", "The impact should be positive if the regulator play their roles"

4.3.2 Activities of Management Measured Up to the Facility Management Regulatory Standards relating to Cold Storage Operations

This section sought to map out the extent to which the activities of management measured up to the facility management regulatory standards relating to cold storage operations. The mean scores with standard deviations as well as the frequency distribution provided enough information to establish the state of the regulatory standards of the cold storage operation.

Table 4.3.2: Activities of Management Measure up to Facility Regulatory Standards

\begin{tabular}{lcccccc}
\hline & SD & D & U & A & SA & $\begin{array}{c}\text { Mean } \pm \text { Std. } \\
\text { Dev. }\end{array}$ \\
\hline $\begin{array}{l}\text { Firms are complying with the regulatory } \\
\text { standards keeping the required temperature }\end{array}$ & $1(2.2)$ & - & $5(11.1)$ & $21(46.7)$ & $18(40.0)$ & $4.22(0.823)$ \\
$\begin{array}{l}\text { Firms are keeping an environment that is } \\
\text { conducive for such an operation }\end{array}$ & $1(2.2)$ & $3(6.7)$ & $6(13.3)$ & $21(46.7)$ & $14(31.1)$ & $3.98(0.965)$ \\
$\begin{array}{l}\text { Firms are considering the health and safety of } \\
\text { the employees and the customers }\end{array}$ & $4(8.9)$ & $3(6.7)$ & $8(17.8)$ & $23(51.1)$ & $7(15.6)$ & $3.58(1.118)$ \\
$\begin{array}{l}\text { The firms are complying as a result of effective } \\
\text { monitoring by the regulators }\end{array}$ & $4(8.9)$ & $6(13.3)$ & $3(6.7)$ & $24(53.3)$ & $8(17.8)$ & $3.58(1.196)$ \\
$\begin{array}{l}\text { The high cost of compliance causes firms to } \\
\text { employ unlawful means to meet the standards }\end{array}$ & $4(8.9)$ & $3(6.7)$ & $8(17.8)$ & $21(46.7)$ & $9(20.0)$ & $3.62(1.154)$ \\
\hline
\end{tabular}

\section{SD: Strongly disagree; D: Disagree, U: Indecisive; A: Agree; SA: Strongly agree}

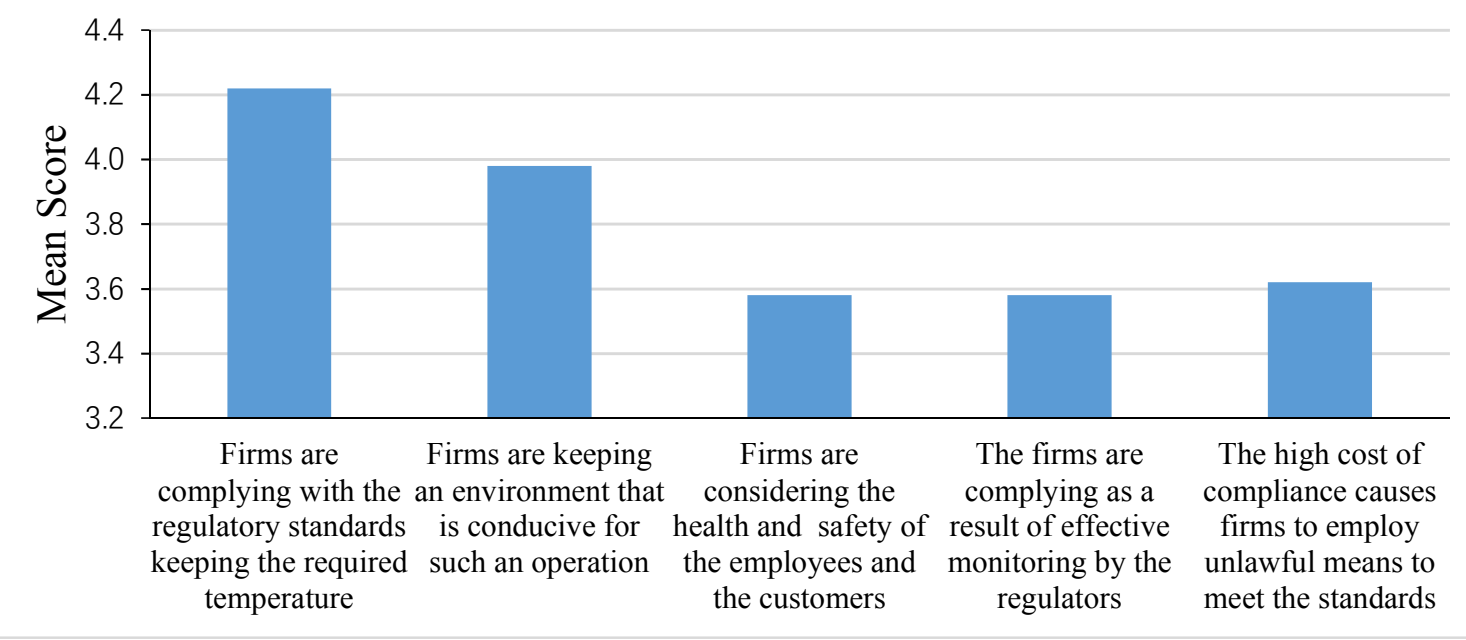

Figure 4.3.2: Activities of Management Measure up to Facility Regulatory Standards 
The extent to which the activities of management measure up to the facility management regulatory standards relating to cold storage operations in Ghana. From the results in (Table 4.3.2), the customers agreed averagely with the following indicators "firms are complying with the regulatory standards keeping the required temperature", "firms are keeping an environment that is conducive for such an operation" and "firms are considering the health and safety of the employees and the customers". The mean scores for these compliance indicators were 4.22 (SD $=0.823), 3.98(\mathrm{SD}=0.965)$ and $3.58(\mathrm{SD}=1.118)$. The other two indicators indicated that the managers were slightly indicated as agreed; "the high cost of compliance causes firms to employ unlawful means to meet the standards", the mean score of $3.58(\mathrm{SD}=1.196)$, and "the firms are complying as a result of effective monitoring by the regulators", the mean score of $3.62(\mathrm{SD}=1.154)$ (Table 4.3.2). The results from the customers suggested the firms are keeping the required temperature, conducive environment of their operation and are considering the health and safety of employees and customers.

\subsubsection{Challenges that Hinder Compliance with Regulatory Standards}

Table 4.3.3: Challenges that Hinder Compliance with Regulatory Standards

\begin{tabular}{|c|c|c|c|c|c|c|}
\hline & SD & D & $\mathbf{U}$ & $\mathbf{A}$ & $\mathbf{S A}$ & $\begin{array}{c}\text { Mean } \pm \text { Std. } \\
\text { Dev. }\end{array}$ \\
\hline $\begin{array}{l}\text { Compliance with regulatory standards } \\
\text { to maintain product quality increases } \\
\text { operational costs (electricity, high cost } \\
\text { of fuel, PPEs, etc) }\end{array}$ & $2(4.4)$ & $8(17.8)$ & $3(6.7)$ & 22( & $10(22.2)$ & $3.67(1.148)$ \\
\hline $\begin{array}{l}\text { Firms feel reluctant to comply because } \\
\text { of duplication of duties of the } \\
\text { regulators }\end{array}$ & $-(\ldots, j)$ & $11(24.4)$ & $5(11.1)$ & $24(53.3)$ & $5(11.1)$ & $3.51(0.991)$ \\
\hline $\begin{array}{l}\text { Firms do not take compliance seriously } \\
\text { due to a lack of knowledge of the } \\
\text { regulations }\end{array}$ & $7(15.6)$ & $7(15.6)$ & $9(20.0)$ & $17(37.8)$ & $5(11.1)$ & $3.13(1.272)$ \\
\hline
\end{tabular}

SD: Strongly disagree; D: Disagree; U: Indecisive; A: Agree; SA: Strongly agree; Std. Dev.:

1. Standard deviation

From (Table 4.3.3), customers averagely agreed on compliance with regulatory standards to maintain product quality increases operational costs (electricity, high cost of fuel, PPEs, etc.) is a challenge hindering compliance with regulatory standards. The mean score recorded for compliance with regulatory standards to maintain product quality increases operational costs (electricity, high cost of fuel, PPEs, etc.) was 3.67 (SD = 1.148), where the majority about 71.1 percent of the customers agreed (48.9 percent agreed and 22.2 strongly agreed).

Firms that feel reluctant to comply because of duplication of duties of the regulators was averagely agreed; about 64.4 percent agreed (53.3 percent agreed and 11.1 percent strongly agreed). However, the customers were neutral that, firms do not take compliance seriously due to a lack of knowledge on the regulations, mean score of $3.13(\mathrm{SD}=1.272), 31.2$ percent disagreed while 48.9 percent agreed.

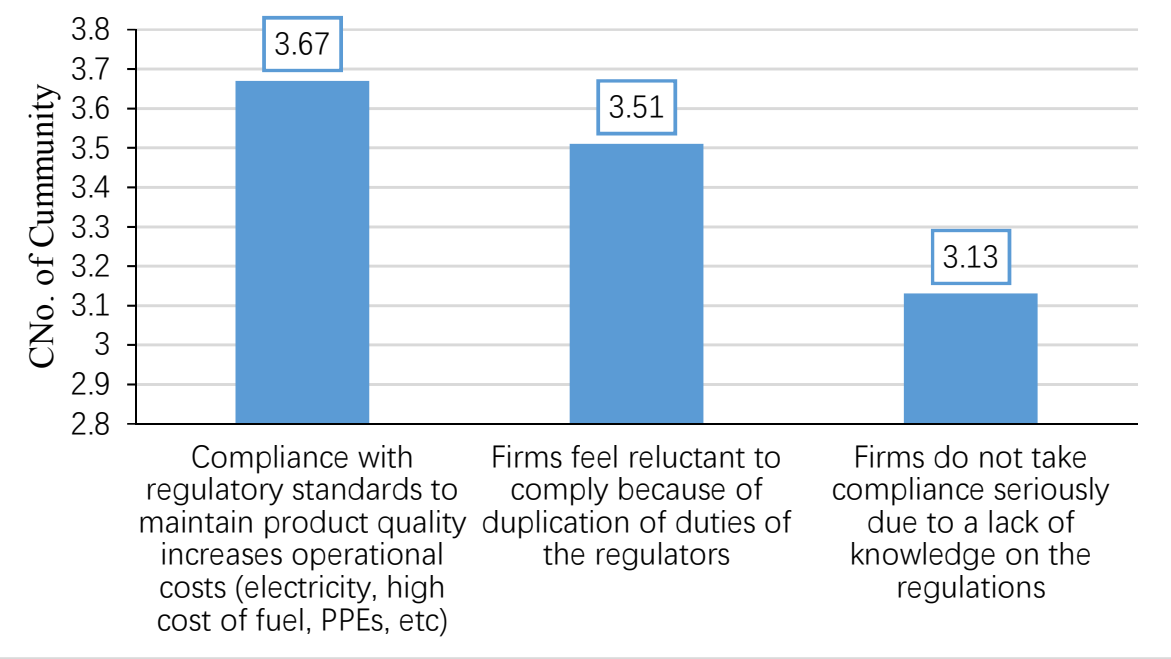

Figure 4.3.3: Challenges that Hinder Compliance with Regulatory Standards 4.3.4 Relationship between Compliance with Regulatory Standards and Profit Level

The relationship between compliance with regulatory standards and profit level was measured in the section. According to the customers' views quality products in the cold storage has an influence on profit and the quality of the product is achieved from compliance with regulatory standards and therefore, the is a relationship between compliance with regulatory standards and profit level. 
Table 4.3.4: Relationship between Compliance with Regulatory Standards and Profit Level

\begin{tabular}{|c|c|c|c|c|c|c|}
\hline & SD & D & $\mathbf{U}$ & $\mathbf{A}$ & SA & $\begin{array}{c}\text { Mean } \pm \\
\text { Std. Dev. }\end{array}$ \\
\hline $\begin{array}{l}\text { The quality of products in the cold storage } \\
\text { facility is due to compliance with regulatory } \\
\text { standards }\end{array}$ & - & $4(8.9)$ & - & $31(68.9)$ & $10(22.2)$ & $4.04(0.767)$ \\
\hline $\begin{array}{l}\text { Full compliance with regulatory standards } \\
\text { has a negative impact on firms' profit } \\
\text { One regulatory body solely for the cold } \\
\text { storage facilities operations instead will be } \\
\text { more convenient }\end{array}$ & $2(4.4)$ & $4(8.9)$ & - & $29(64.4)$ & $10(22.2)$ & $3.91(0.996)$ \\
\hline
\end{tabular}

SD: Strongly disagree; D: Disagree, U: Indecisive; A: Agree; SA: Strongly agree

The customers strongly agreed on average that, the quality of products in the cold storage facility is due to compliance with regulatory standards, mean score of $4.04(\mathrm{SD}=0.767) ; 68.9$ percent agreed and 22.2 percent strongly agreed (Table 4.3.4). The second indicator that was averagely agreed was that one regulatory body solely for the cold storage facilities operations instead will be more convenient, a mean score of $3.98(\mathrm{SD}=1.097)$. About 86.7 percent of the customers at least agreed to full compliance with regulatory standards has a positive impact on firms' profit. In addition, the majority of customers, 86.6 percent (64.4 percent agreed and 22.2 percent strongly agree) revealed compliance with regulatory standards has a negative impact on firms' profit.

\subsection{Heads of Department}

\subsubsection{Demographic Information of the Regulators (Heads of Department)}

The background information of the participants of regulators (heads of departments) was Ghana Standard Authority (GSA), Tema Municipal Assembly (TMA), Factory inspectorate, Port Health, Environmental Protection Agency, and Food and Drug Authority. The ages of the respondents were all above 40 years and had averagely registered 20 (mean score 20.2) firms with the institutions.

\subsubsection{Facility Management Regulatory Standards Relating to Cold Storage Operations in Ghana}

This section sought to examine the facility management regulatory standards relating to cold storage operations in Ghana. The focus of this was to ascertain the roles played by the various regulators in cold storage facilities operations, various standards guiding the cold storage facilities operations, the extent to which firms are complying with the standards, and the extent the regulatory laws or policies support the effective delivery of their work.

1. Roleplay in cold storage facilities operations

From the result (Table 4.4.1), a participant from Ghana Standard Authority said that their role was to ensure the cold storage facilities comply with the requirement of the fishery product regulation (GS FPR1 2007). The role of the Food and Drug Authority is to ensure the registration of products in the cold storage facilities, inspection and licensing of the facilities, training of operators of cold storage facilities, development of guidelines codes of practices and regulation for the cold storage industry, and supervision of repackaging, relabeling and safe disposal of products in the facility.

Environmental Protection Authority operates under EPA Act 1994 L1162 which ensures environmental protection and technical issues. Factory inspectorate ensures occupational safety and health auditing and TMA is in charge of the inspection of the structure, machines, sanitary, and water systems. From the roles played by the six regulatory authorities, each institution has a unique role to play in relation to cold storage facility operations.

Table 4.4.1: Roleplay in cold storage facilities operations

\begin{tabular}{ll}
\hline \multicolumn{1}{c}{ Institution } & \multicolumn{1}{c}{ Roles } \\
\hline GSA & We ensure the cold storage facilities comply with the requirement of the fishery \\
pMA & Inspection of structure, machines, sanitary, water systems, \\
Factory inspectorate & $\begin{array}{l}\text { Occupational safety and health auditing } \\
\text { Port Health }\end{array}$ \\
EPA & WPolesomeness, statutory condition \\
& and technical issues \\
& Registration of products in the cold storage facilities \\
& Inspection and licensing of the facilities \\
& Training of operators of cold storage facilities \\
& Development of guidelines codes of practices and regulations for the cold storage \\
FDA & industry \\
& Supervision of repackaging, relabeling, and safe disposal of products in the facility
\end{tabular}




\section{Table 4.4.2: Various Standards Guiding the Cold Storage Facilities Operations}

$\begin{array}{ll}\text { GSA } & \text { Fishery product regulation (GS FPR1; 2007) } \\ & \text { Codes of practices for cold storage facilities } \\ \text { GS 90:2015 (meat and meat products for fresh } \\ \text { FDA } & \text { GS 91:2015 (meat and meat products for fresh, chilled frozen poultry) } \\ & \text { The food handles, PPEs confirmation, room arrangement, waste management } \\ \text { TMA } & \begin{array}{l}\text { EPA Act 1994 L1162 -mandates, EPA Act 2019 L1238-fee, National investment } \\ \text { promotion Act Article }\end{array} \\ \text { EPA } & \text { Public health Act } 851 \text { 2012, international health register 2005 criminal code Act } 291960 \\ \text { PORT HEALTH } & \text { The factories officers and shops Act 328(1970) and regulated law and regulation } \\ \text { Factory } & \end{array}$

The FDA stated the following codes of practices guiding cold storage facilities (Table 4.4.2); GS 90:2015 (meat and meat products for fresh, GS 91:2015 (meat and meat products for fresh, chilled frozen poultry) and GS 92:2015 (meat and meat products for fresh mutton). GSA has fishery product regulation (GD FPR1; 2007). The EPA is guided by EPA Act 1994 L1162 - mandates, EPA Act 2019 L1238-fee, National investment promotion Act Article. Port health is guided by Public Health Act 851 2012, international health register 2005 criminal code Act 29 1960, and factory inspectorate is guided by the factories officers and shops Act 328(1970) and regulated law and regulation.

1. Extent the firms complying with the standards

About 50 percent of the heads rated the extent of the firms complying with the standards to 80 percent compliance. Another participant said compliance of firms with the standard was about 70 percent. It was explained that some cold storage facilities have gotten the approval to export fish to the Europeans Union and other countries. This means that the structure and the cold storage facilities meet the regulatory requirement. Another respondent rated the firms' compliance with standards fairly well. This was rated so because there are times non-compliance raised is not addressed within the agreed time frame. Some clients also do not readily renew their facility licenses when the validity elapses.

\section{Table 4.4.3: The extent to the firms comply with the standards}

\begin{tabular}{|c|c|c|}
\hline & $\mathbf{N}$ & Percent \\
\hline $\begin{array}{l}\text { Cold storage facilities that have the approval to export fish to the Europeans Union and } \\
\text { other countries. This means that the structure and the cold storage facilities meet } \\
\text { regulatory requirement }\end{array}$ & 1 & 16.7 \\
\hline Compliance is about $70 \%$ & 1 & 16.7 \\
\hline Compliance is about $80 \%$ & 3 & 50.0 \\
\hline $\begin{array}{l}\text { It's been fairly good. There are times non-compliance raised is not addressed within the } \\
\text { agreed time frame. Some clients also do not readily renew their facility license when the } \\
\text { validity elapses }\end{array}$ & 1 & 16.7 \\
\hline Total & 6 & 100.0 \\
\hline
\end{tabular}

Table 4.4.4: The extent to the regulatory laws or policies support the effective delivery of work

It is cost-effective

Measures put in place, temperature to be quality

Non-compliance notification

Regulatory laws are adequate for effective enforcement

The law is (1970) and must be modernized and does not fully support the delivery of one work.

The storage facility is capable of storing at $18 \mathrm{C}$ or less (cold room), the structure is made of solid construction to protect the fishery product from possible contaminated

Some of the heads described the extent to which regulatory laws or policies support the effective delivery of work as cost-effective and adequate. This suggests the regulatory laws and policies are adequate for effective enforcement. The followings were their responses (Table 4.4.4); "It is cost-effective", "Regulatory laws are adequate for effective enforcement" and "Measures put in place, temperature to be quality". However, it was argued the laws are too outmoded thus, made (1970) and must be modernized because it does not fully support the delivery of one work in modern times. "The laws are (1970) and must be modernized and does not fully support the delivery of one work". The storage facility is capable of storing at $18 \mathrm{C}$ or less (cold room), the structure is made of solid construction to protect the fishery product from possible contamination. This was the response "The storage facility is capable of storing at $18 \mathrm{C}$ or less (cold room), the structure is made of a solid construction to protect the fishery product from possible contaminated". 


\subsubsection{Challenges that Hinder Compliance with Regulatory Standards}

The other challenges that hinder compliance with regulatory standards were the high cost of mechanicals, lack of definitive standards and policy, low level of education among operators on roles of the regulators, reluctance for people to allow inspection, and lack of finance. About 50 percent of the heads indicated that firms are reluctant to comply with the standard due to low publicity. It was also supported by one of the participants that political interference also contributes to a firm's reluctance to comply with the standard due to low publicity. The majority of the respondents, 66.7 percent (Table 4.4.5) indicated the roles of the various regulators seem to be duplicated, while the remaining said their roles are not duplicated. The same way the current ways of managing cold storage facilities call for changes. It was observed that 50 percent (Table 4.4.5) of the respondents were of the view that, to save cost and time the firms can employ self-regulatory systems because their prime aim is maintaining product quality. The heads also were of the view that strict regulatory standards enhance innovation. They explained that companies have employed ways of avoiding breaking of the cold chain which may lead to public health concerns and hence strict regulatory standards the solution. Some firms have ingenerated to ensure maintenance of product safety and quality.

Table 4.4.5: Challenges that Hinder Compliance with Regulatory Standards

\begin{tabular}{|c|c|c|}
\hline & $\mathbf{N}$ & Percent \\
\hline Other challenges & - & \\
\hline Fees, lack of financial & 1 & 16.7 \\
\hline High cost of mechanicals & 2 & 33.3 \\
\hline Lack of definitive standard and policy & 1 & 16.7 \\
\hline Low level of education among the operators & 1 & 16.7 \\
\hline Reluctant for people to allow inspection & 1 & 16.7 \\
\hline Firms are reluctant to comply with the standard due to low publicity & - & \\
\hline Yes & 3 & 50.0 \\
\hline No & 2 & 33.3 \\
\hline Political interference & 1 & 16.7 \\
\hline Total & 6 & 100.0 \\
\hline The roles of the various regulators seem to be duplication & - & \\
\hline Yes & 4 & 66.7 \\
\hline No & 2 & 33.3 \\
\hline Total & 6 & 100 \\
\hline The current ways of managing cold storage facilities call for changes & - & \\
\hline Yes & 4 & 66.7 \\
\hline No & 2 & 33.3 \\
\hline Total & 6 & 100.0 \\
\hline \multicolumn{3}{|c|}{$\begin{array}{l}\text { Think to save cost and time the firms can employ self-regulatory systems because their } \\
\text { prime aim is maintaining product quality }\end{array}$} \\
\hline Yes & 3 & 50.0 \\
\hline No & 3 & 50.0 \\
\hline Total & 6 & 100.0 \\
\hline \multicolumn{3}{|l|}{ Strict regulatory standards enhance innovation } \\
\hline Yes & 5 & 83.3 \\
\hline No & 1 & 16.7 \\
\hline Total & 6 & 100.0 \\
\hline
\end{tabular}

4.4.5: Recommendations of the Regulators

1. The measures recommended putting in place to ensure full compliance

The followings were the measures recommended by the heads of department to put in place to ensure full compliance with the regulatory standard of the cold storage operation. From the table (Table 4.4.6), the recommendations were on education, creation of awareness, increasing visits to facilities, conforming existing laws with modern trends, reduction of political interference, reduction of duplication of work, strict and effective enforcement of the law. The heads recommended for public education on compliance of facility operation; it was mentioned as "provide education", "increase publicity" and "public education". This suggests that would improve compliance with the regulatory standard, institutions involved should provide education to the public to help ensure full compliance. The followings were the recommended ways the firms can employ to enhance product quality and at the same time minimize operational cost; Collaboration of cold rooms, minimizing direct access of the cold rooms to the external environment, maintenance of the equipment used to ensure efficiency, adherent to the regulatory requirement to avoid poor quality products, provision of PPEs, selection and implementation of a safety officer and manager and allowing individuals to lure with their medical certificate. The heads of departments were asked to express their views on whether there is a strong relationship between compliance with regulatory 
standards and firms' profit. From the responses (Table ...), two of the heads of departments supported that there was a strong relationship between compliance with regulatory standards and firms' profit. Adding that, a company that complies fully always has good quality products for sale and does not attract sanctions which affects the profit negatively. Quality and safe products reassured firms complying with regulatory standards receive the first point of contact hence the positive association between compliance and firms' profit. One of the participants from the heads posed that, compliance ensures quality through mandate and therefore not related to relationship with firms' profit. The result showed a majority of the participants from the institutional heads made known that there is a direct relationship between compliance with regulatory standards and firms' profit. The strength of the relationship was as a result of having good quality products for the client which subsequently attract more clients and therefore high profit for the said company. This also safe the company from being sanctioned for supplying bad products to customers. The government to merge regulatory agencies assigned to cold storage firms into one agency for effective monitoring and control.

The heads of the department were all of the views that all the agencies have their well-defined mandate as stipulated in the drafted food safety policy and to carry out the same function. The collaboration of these agencies should therefore be strengthened to provide effective monitoring and control.

Table 4.4.6: Recommendations from the Heads of Departments

\begin{tabular}{|c|c|c|c|}
\hline $\begin{array}{l}\text { The measures } \\
\text { recommended to put in } \\
\text { place to ensure full } \\
\text { compliance }\end{array}$ & $\begin{array}{l}\text { Ways the firms can } \\
\text { employ to enhance } \\
\text { product quality, at the } \\
\text { same time minimizing } \\
\text { operational cost }\end{array}$ & $\begin{array}{l}\text { Think there is a strong } \\
\text { relationship between } \\
\text { compliance with regulatory } \\
\text { standards and firms' profit }\end{array}$ & $\begin{array}{l}\text { The government to merge } \\
\text { regulatory agencies } \\
\text { assigned to cold storage } \\
\text { firm into one agency for } \\
\text { effective monitoring and } \\
\text { control }\end{array}$ \\
\hline $\begin{array}{l}\text { Education and awareness } \\
\text { creation }\end{array}$ & $\begin{array}{l}\text { Calibration of cold } \\
\text { rooms, minimizing direct } \\
\text { access of the cold rooms } \\
\text { to the extemal } \\
\text { environment }\end{array}$ & $\begin{array}{l}\text { Compliance ensure quality } \\
\text { through mandate is not related to } \\
\text { that }\end{array}$ & $\begin{array}{l}\text { Collaboration should be } \\
\text { strengthened }\end{array}$ \\
\hline $\begin{array}{l}\text { Increase in publicity and } \\
\text { visibility, } \\
\text { Increased regularity of } \\
\text { facility visits conforming } \\
\text { existing laws with } \\
\text { modem trends }\end{array}$ & $\begin{array}{l}\text { Maintenance of the } \\
\text { equipment used to ensure } \\
\text { efficiency } \\
\text { Adhering to regulatory } \\
\text { requirement to avoid } \\
\text { poor quality products }\end{array}$ & Undecisive & $\begin{array}{l}\text { No. } \\
\text { All the agencies have their } \\
\text { well-defined mandate as } \\
\text { stipulated in the drafted } \\
\text { food safety policy and to } \\
\text { carry out the same } \\
\text { functions }\end{array}$ \\
\hline Public education & $\begin{array}{l}\text { Provide PPEs } \\
\text { Allow individuals to lure } \\
\text { with their own medical } \\
\text { certificate }\end{array}$ & $\begin{array}{l}\text { Yes, positive. } \\
\text { A company which complies fully } \\
\text { will always have good quality } \\
\text { products for sale and will not } \\
\text { attract sanctions which will affect } \\
\text { the profit negatively }\end{array}$ & $\begin{array}{l}\text { There should be } \\
\text { collaboration }\end{array}$ \\
\hline $\begin{array}{l}\text { Reduce political } \\
\text { interference } \\
\text { Duplication of work } \\
\text { must be reduced }\end{array}$ & $\begin{array}{l}\text { Selection and } \\
\text { implementation of a } \\
\text { safety officer and } \\
\text { managers }\end{array}$ & $\begin{array}{l}\text { Yes } \\
\text { Since quality and safe product re } \\
\text { assured hence the firm } \\
\text { complying will be first point of } \\
\text { contact }\end{array}$ & $\begin{array}{l}\text { They would be difficult to } \\
\text { implement }\end{array}$ \\
\hline $\begin{array}{l}\text { Strict enforcement of the } \\
\text { laws and standards } \\
\text { At times due to lack of } \\
\text { some resource } \\
\text { enforcement may not be } \\
\text { very effective }\end{array}$ & Undecisive & & \\
\hline
\end{tabular}

\subsection{Report on Inspectorate Data}

\subsubsection{Background Characteristics of the Regulators}

This section presented the results of the inspectorate responses of the three participants from the institutions' inspectorate of facilities. From the results of the inspectorate, three institutions participated in the study; via GSA, FDA and inspectors, TMA Port Health EPA, and Department of Factories Inspectorate. There were 66.7 percent male and 33.3 percent female. The age bracket of the inspectors comprised 20-30 years, 31-40 years, and above 40 years.

4.5.2 The Extent to which the Activities of Management Measure up to the Facility Management Regulatory Standards

The inspectors' responses to measure the extent to which the activities of management measuring up to the facility 
management regulatory standards were presented in this section. The analysis was carried out with the use of a mean score with a standard deviation of the mean, together with the percentage distribution of the scales used for the measurement.

Table 4.5.1: The Extent to which the Activities of Management Measure up to the Facility Management Regulatory Standards

\begin{tabular}{|c|c|c|c|c|c|}
\hline & Mean (SD) & SD & D & $\mathbf{A}$ & $\mathbf{S A}$ \\
\hline $\begin{array}{l}\text { Firms are complying fully with the regulatory standards keeping } \\
\text { the required temperature }\end{array}$ & $4.33(0.577)$ & - & - & 66.7 & 33.3 \\
\hline $\begin{array}{l}\text { Firms are keeping an environment that is conducive for such an } \\
\text { operation }\end{array}$ & $3.67(1.528)$ & - & 33.3 & 33.3 & 33.3 \\
\hline $\begin{array}{l}\text { Firms are considering the health and safety of the employees } \\
\text { and the customers }\end{array}$ & $4.33(0.577)$ & - & - & 66.7 & 33.3 \\
\hline $\begin{array}{l}\text { The firms are complying as a result of effective monitoring by } \\
\text { the regulators }\end{array}$ & $4.33(0.577)$ & - & - & 66.7 & 33.3 \\
\hline $\begin{array}{l}\text { The high cost of compliance causes firms to employ unlawful } \\
\text { means to meet the standards }\end{array}$ & $2.33(1.528)$ & 33.30 & 33.3 & 33.3 & - \\
\hline
\end{tabular}

From (Table 4.5.1), three of the assertions of the extent to which the activities of management measure up to the facility management regulatory standards relating to cold storage operations were rated as high. In other words, these activities were considered by the inspectors as the firms were up to the facility management regulatory standards relating to cold storage operations. These indicators were that; the firms are complying fully with the regulatory standards keeping the required temperature at the facility. The second indicator was that firms are considering the health and safety of the employees and the customers, and the firms are complying as a result of effective monitoring by the regulators. From the distribution (Table 4.5.1), 66.7 percent of the inspectors agreed and 33.3 percent strongly agreed to the assertions on the activities of the firms measure up to the facility management regulatory standards relating to cold storage operations. It was also agreed by the inspectors (66.7 percent at least agreed) that firms are keeping an environment that is conducive for such an operation. However, about 33.3 percent disagreed that firms are keeping an environment that is conducive for cold storage operations. However, a greater percentage of the inspectors disagreed that, there was a high cost of compliance that caused firms to comply with unlawful means to meet the standards. 33.3 percent of the inspectors agreed high cost of compliance to the firms causes them to employ unlawful means to meet the standards.

4.5.3 Challenges that Hinder Compliance with Regulatory Standards

According to the views of the inspectors, compliance with regulatory standards to maintain product quality does not increase operational costs (Electricity, high cost of fuel, PPEs. Etc.). This statement was averagely disagreed by the inspectors, mean score of 3.33 strongly disagree and 3.33 disagree indicating majority disagreed that "Compliance with regulatory standards to maintain product quality increases operational costs. (Electricity, high cost of fuel, PPEs. Etc.)". Similarly, the inspectors disputed the fact that the role of the regulators of duplication of duties of the regulators is a challenge that hinders compliance with regulatory standards. It is also not true that some firms do not take compliance seriously due to a lack of knowledge of the regulations. They do not believe that firms can comply better without much supervision from regulators. The only challenge in which facility inspectors averagely agreed was the fact that strict regulatory standards do not enhance innovative ideas.

Table 4.5.2: Challenges that Hinder Compliance with Regulatory Standards

\begin{tabular}{|c|c|c|c|c|c|}
\hline & Mean (SD) & SD & D & $\mathbf{A}$ & SA \\
\hline $\begin{array}{l}\text { Compliance with regulatory standards to maintain product } \\
\text { quality increases operational costs. (Electricity, high cost of } \\
\text { fuel, PPEs. Etc.) }\end{array}$ & $3.33(2.082)$ & 33.3 & 33.3 & 33.3 & - \\
\hline $\begin{array}{l}\text { The role of the regulators of duplication of duties of the } \\
\text { regulators }\end{array}$ & $2.33(1.528)$ & 33.3 & 33.3 & 33.3 & - \\
\hline $\begin{array}{l}\text { Some firms do not take compliance seriously due to a lack } \\
\text { of knowledge of the regulations }\end{array}$ & $3.00(1.732)$ & - & 66.7 & - & 33.3 \\
\hline Strict regulatory standards do not enhance innovative ideas & $3.67(1.528)$ & - & 33.3 & 33.3 & 33.3 \\
\hline $\begin{array}{l}\text { Firms can comply better without much supervision from } \\
\text { regulators }\end{array}$ & $2.33(1.528)$ & 33.3 & 33.3 & 33.3 & - \\
\hline
\end{tabular}

4.5.4 Relationship between Compliance with Regulatory Standards and Profit Levels

This section measured the views of the regulators on the relationship between compliance with regulatory standards and profit levels. 
Table 4.5.3: Relationship between Compliance with Regulatory Standards and Profit Levels

\begin{tabular}{|c|c|c|c|c|c|}
\hline & Mean (SD) & SD & D & $\mathbf{A}$ & SA \\
\hline $\begin{array}{l}\text { The quality of the product in the cold storage facility is due to } \\
\text { compliance with regulatory standards }\end{array}$ & $3.33(2.082)$ & 33.30 & - & 33.3 & 33.3 \\
\hline Full compliance with regulatory standards harms firms' profit. & $2.33(1.528)$ & 33.00 & 33.3 & 33.3 & - \\
\hline $\begin{array}{l}\text { One regulator specifically for cold storage operations will be } \\
\text { convenient for smooth operations }\end{array}$ & $2.67(2.082)$ & 33.30 & 33.3 & - & 33.3 \\
\hline $\begin{array}{l}\text { Downsizing regulators for cold storage firms will reduce } \\
\text { operational cost and maximize profit }\end{array}$ & $3.33(2.082)$ & 33.30 & - & 33.3 & 33.3 \\
\hline $\begin{array}{l}\text { There exists a strong relationship between compliance with } \\
\text { regulatory standards and firms profit }\end{array}$ & $4.67(0.577)$ & - & - & 33.3 & 66.7 \\
\hline
\end{tabular}

There exists a strong relationship between compliance with regulatory standards and firms' profit. This suggested that firms adherent to the regulatory standards foster the level of profit. The mean score was very high, $4.67(\mathrm{SD}=0.57)$ indicating inspectors' collective agreed there is a strong relationship between compliance with regulatory standards and firms' profit. The majority of the inspectors agreed on average that, downsizing regulators for cold storage firms will reduce operational cost and maximize profit, and also the quality of the product in the cold storage facility is due to compliance with regulatory standards. These items according to the inspectors have an inherent positive relationship between compliance standards and profit level.

Participants disagreed that full compliance with regulatory standards harms firms' profit, and one regulator specifically for cold storage operations will be convenient for smooth operations. This result demonstrated that there exists a positive relationship between compliance with regulatory standards and firms' profit. This was in support of the assertion made that "there exist a strong relationship between compliance with regulatory standards and firms' profit. It was also made clear from the responses of the inspectors that one regulator specifically for cold storage operation would be convenient for smooth operations.

\section{ANALYSIS OF RESULTS, VERIFICATION, AND SUGGESTIONS 5.1 Analysis of Results Based On Data}

With regards to the participant, more than average was able to respond while a few like the field inspectors were out on duty and due to time limitations, the researcher could not wait for all the responses. The result showed that 15 of the managers were in their active service and effective enough to have provided the responses on the impact of regulatory standards on firms' profit. The report confirmed that all the respondents occupied top positions (Owners) and the facilities were mainly owned by their respective firms. It is worthy to note that it is a requirement for all firms operating cold storage businesses to register with the regulators so the issue of unregistered firms was ruled out. All the firms sampled also had a least more than one branch under the same owner in that case the researcher could not send the same questions to all the branches except one. This was to avoid the repetition of responses. A few of the cold storage firms were found to have been rented from individuals or the state. Customers were also involved to help confirm if the words of both the managers and the regulators were the actual situation in the firms. A total of 45 customers were randomly selected from different firms. Some of these participants were known to be retailers, agents or middlemen, and individuals who purchase for personal consumption. most of them purchased at least twice a week and once in a month respectively. These confirm that majority of the customers were abreast with the activities of the firms and aware of the regulatory standards that govern cold storage firms. Concerning the regulators which were Food and Drugs Authority, (FDA) Ghana Standards Authority (GSA), Environmental Protection Agency (EPA), Tema Municipal Assembly (TMA), Department of Factories Inspectorate (DFI), and Port Health, there was an indication that majority were tertiary graduates in their field of work and therefore had the in-depth the knowledge on cold storage operations. The result showed that between $53 \%$ and $80 \%$ were aware of the regulators and this made the objective of the response. All this affirms that knowledge can be generated and understood from the point of view of the individuals who live and work in a particular environment. (Sunders \& ThornHill, 2007, Lundgren, et al (2017) ${ }^{[48[49]]}$ as indicated in the review.

\subsection{SUMMARY OF RESULTS \\ The Research Findings}

1. With regards to knowledge on regulators and their various standards on cold storage facility management and how firms are complying, the various standards from various participants which were outlined as temperature control, calibration, health and safety of personnel and customers, and environmental cleanliness which is in line with FDA Public Act 2012, Act 851, Part Seven, Section 148, Subsection (2g). The result proved that majority of the respondents were highly knowledgeable in that aspect.

2. However, the response showed no information on the Department of Factories Inspectorate which is an indication that people (Managers and Customers) have less knowledge about their activities. In other words, their visibility especially in the cold storage operations is very minimal and this result goes to affirm that the 
department is not that effective in monitoring and control as a result of a lack of resources to execute their mandate. 3. On the issue of whether the activities of the regulators supported the activities of the firms, it was revealed that the majority were of the view that maintaining good temperature, hygiene, and a safe working environment were considered to be the driving force for product quality. This was being enforced by all the regulators and the firms were of the view that it supports their work and all accepted that it aids in ensuring product quality. This goes to prove that when the firms adhere to standards and the regulators play their roles as well by putting in place effective monitoring and control systems the quality for the product will improve and this calls for a collation between the firms and the regulators.

4. Concerning the roles of the regulators, $66.7 \%$ of the firms responded that the roles of the regulators seem to be duplicating since, in the end, they all look for one result which is Product quality. Therefore, the result shows $86 \%$ a calling for the regulators to be merged some of the regulators and overhauling, however, the regulators think there should rather be a collaboration each regulator play a unique role, as such there should be publicity and education on roles of the regulators.

5. It also came to light that the laws and policies were outdated and do not sometimes conform with the current situation.

6. The question of whether the quality of the product is due to compliance of regulatory standards, about $73 \%$ confirmed the product quality is always high when there is compliance and therefore they are all of the views that there is a strong relationship between the quality of the product and regulatory standards. It can then be said that when good practices are adhered to, there would be profitability.

7. Finally, Majority objected that stringent regulatory standard bring about innovation, this statement per the views of the respondents could not be applied in the cold storage operations. Stringent regulatory standards rather bring about illegality in the operations.

8. The findings of this study proved that there is a strong and positive relationship between product quality and firm profit. This confirms the statement that there is a positive, significant managerial aspect on firms' performance and profitability. This means that when management decides to adhere to regulatory standards, the product quality will be enhanced and the firm will be able to sell large volumes and as sales (sales at market price) go up, profit increases

9. An assumption was also proven by the responses that quality is a determinant of profit in cold storage operations and product quality can be achieved when there is adherence to facility management regulatory standards. This means there is a strong relationship between regulatory standards and a firm's profit and the impact is positive. From the views of the managers and as they quoted, "compliance improve the quality of products which increase trust and sales which affects profit levels positively" (cold Storage Managers in Ghana, 2021). ${ }^{[51]}$

\subsection{Profit Analysis of the Firms within the Three years}

This section presented the profit level of the firms from 2017 to 2019 financial years (profit declared at the end of the financial years). The average profit recorded for the 15 firms in the study within the three years was $\mathrm{GH} \notin 482,888.66$ with a standard deviation of GH $\notin 452,706.26$. The minimum profit made was GH $\notin 21,327.56$ and the highest profit recorded within the period was GHф1,588,997.00 (Table 1).

The trend of the period revealed profit level of the firms increased significantly. From Table 1 and Figure, the firms recorded $\mathrm{GH} \not 155,095.35$ in 2017 which is the lowest profit in the period was a time the country had challenges with power supply and firm's had to rely most often on generators. In 2018, the increase in profit was almost thrice of 2017 profit, thus, GHф453,547.58, and the profit made by the firms in 2019 was GHф840,023.05 also almost twice of 2018 profit recorded. The results showed the profit for the firms had increased significantly within the period. This result could be inferred to support the views of the stakeholders of cold storage operations that, compliance with regulatory standards of cold storage operation had a strong relationship with the firms' profit.

Table 1: Profit Level of the Firms in the Study within the Three-Year Period

\begin{tabular}{llllll}
\hline Years & N & Mean & Std. Deviation & Minimum & Maximum \\
\hline 2017 & 15 & $155,095.35$ & $230,200.78$ & $21,327.56$ & $967,162.00$ \\
2018 & 15 & $453,547.58$ & $385,886.10$ & $66,421.00$ & $1,588,997.00$ \\
2019 & 15 & $840,023.05$ & $435,321.60$ & $33,632.50$ & $1,347,814.97$ \\
Overall Statistics & $\mathbf{4 5}$ & $\mathbf{4 8 2 , 8 8 8 . 6 6}$ & $\mathbf{4 5 2 , 7 0 6 . 2 6}$ & $\mathbf{2 1 , 3 2 7 . 5 6}$ & $\mathbf{1 , 5 8 8 , 9 9 7 . 0 0}$ \\
\hline
\end{tabular}




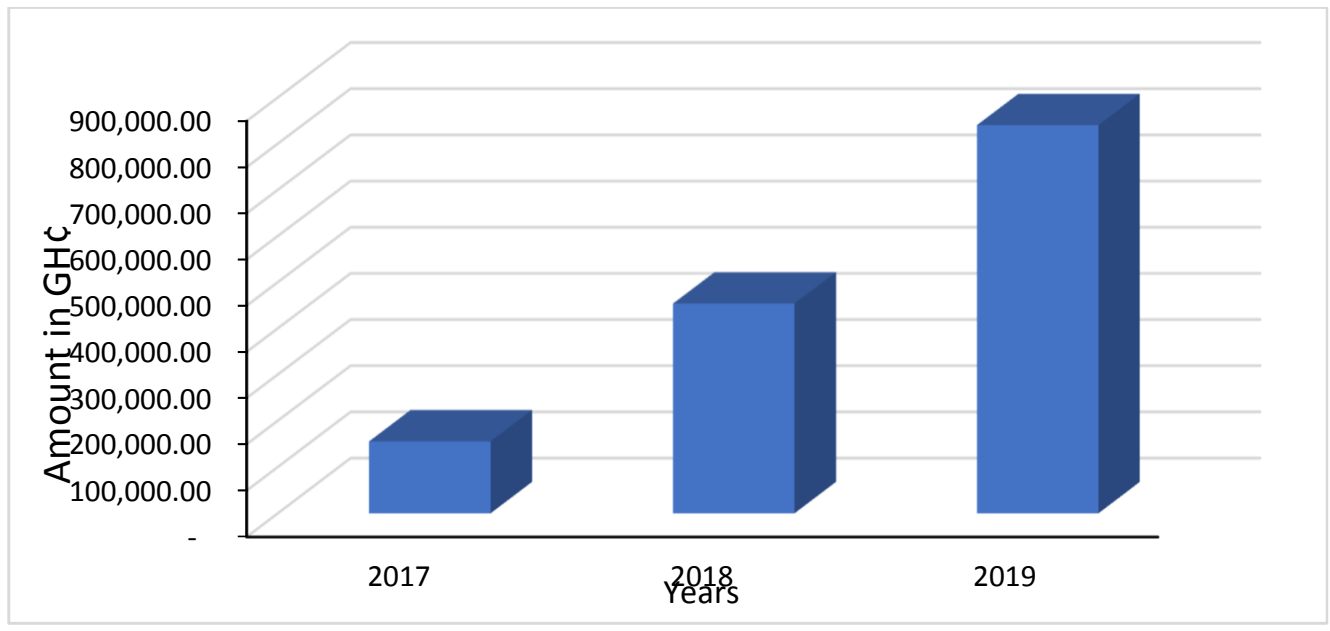

\subsubsection{Managerial Suggestions}

Figure 4.5.1: Profit Level of the Firms

The following was there a suggestion for the Cold Storage Firms;

1. Managers must have their own SOPs as well as qualified safety officers who will ensure that there is full compliance to avoid penalties that may have a negative effect on both the firm's profit and reputation.

2. To save cost, the firms can allow individuals seeking employment to lure with their medical certificates

3. Firms are to adhere to the regulatory requirements to avoid the poor quality of products which may affect firm

4. To avoid unnecessary interruptions caused by the sudden breakdown of equipment, the firms must develop a maintenance culture to ensure the efficiency of machines.

5. The firms must also provide PPEs to protect the workers from the cold and other injuries which may come as an extra cost for the firm.

6. There should be frequent calibrations and minimize direct access of cold stores to the external environment.

7. In addition, the firms can also use energy-saving equipment and also keep the cold room doors closed especially during the hot seasons. This will help prevent too much heat from entering the room.

\section{Conclusion and Future Prospects of the study}

The study was about, "the impact of facility management regulatory standards on firms' profit based on cold storage operations in the Tema Metropolitan Assembly. Regulatory standards provide measures that focus on productivity. The pursuit for product quality is not only achieved by enhancing technologies and other hi-tech equipment, or the best customers but driven by the need for firms to maintain a good temperature. It can be said that it rather costs less to follow standards than leaving products unattended to deteriorate. This situation when encountered may dwindle profit, affect the firms' reputation, or at worse incur sanctions and business closure. Overall the empirical findings of this study suggest that the quality of the product has a positive impact on profitability and comes as a result of adhering to facility management regulatory standards. The finding suggests several issues; firstly, it was established that quality increases sales which have a positive impact on profitability, however, the duty lies solely on the managers or owners of the firms to adhere to regulatory standards. Secondly, the regulators have a burden to monitor and control the operations of the firms to ensure that the required standards are adhered to without fear or favor. The regulators are also encouraged to avoid exhortation or bribery as a coverup for unacceptable behaviors. Thirdly, the duty also lies on the customers to report any activity deemed as unacceptable and are been conducted by firms such as selling of unwholesome products to the public, instead of destroying them to the respective regulator. Fourthly, the government needs to support various regulatory institutions with the necessary logistics to enable them to work effectively and also without any political interference as was purported. The main conclusion that emerged from this study is that adhering to regulatory standards holistically will ultimately result in a positive gain. The results, therefore, validated some of the key linkages and support for briefs and evidence by various researchers in other studies that showed the relationship between quality and profitability. Adhering to regulatory standards helps to maintain the right temperature and keeps the products free from deterioration, at the same time reducing occupational hazards. It also reduces disruptions due to frequent breakdowns of machinery. No doubt adhering to standards and product quality go hand in hand as both the managers and regulators play their roles effectively. It is also important that laws and policies regarding various standards must be revised to meet the current situation. Again all firms must be treated equally and fairly without partiality and free from political influence. the purpose of this study makes it explicit that there is an impact of facility management regulatory standards on firms' profit and it can be positive only when the 
firms adhere to facility management regulatory standards.

\section{Bibliography}

[1] Amin, M. K., \& Zaman, M. (2020). Which Comes First in the Apparels Industry: Process or Compliance? doi: $10.4135 / 9781529700770$

[2] Appiah, Samson O. (2013). "Workplace Safety in Ghana: A study of the Pioneer Food Cannery, Tema”, Legon Journal of Sociology, 5(1):1-21.

[3] Asiedu, B. (2018). The performance of tuna processing fishery sector to sustainable fish trade and food security in Ghana. Journal of Energy and Natural Resource Management, 2(1), 8-14. doi:10.26796/jenrm.v2i0.39

[4] AYDIN, A., \& BASHIMOV, G. (2020). Determination of Fish Consumption Habits of Consumers: Case Study of Mary City, Turkmenistan. Marine Science and Technology Bulletin, In Press, 118-124. doi:10.33714/masteb.685436

[5] AYDIN, A., \& BASHIMOV, G. (2020). Determination of Fish Consumption Habits of Consumers: Case Study of Mary City, Turkmenistan. Marine Science and Technology Bulletin, In Press, 118-124. doi:10.33714/masteb.685436

[6] Çalı, B. (2015). The Authority of International Law. The Authority of International Law, 49-86. doi:10.1093/acprof:oso/9780199685097.003.0003

[7] Calvert, J. G. (2016). Controlled Atmosphere. IUPAC Standards Online. doi:10.1515/iupac.62.0181Feedback: support@crossref.org

[8] Chen, Cheng. 2017. "Management Quality and Firm Hierarchy in Industry Equilibrium." American Economic Journal: Microeconomics, 9 (4): 203-44.

[9] Chiekezie, O. M. (2017). Maintenance Culture And Performance Of Selected Manufacturing Firms In Benue State, Nigeria. Archives of Business Research, 5(3). doi:10.14738/abr.53.2803

[10] Creswell, J.W. and Creswell, J.D., 2017. Research design: Qualitative, quantitative, and mixed methods approaches. Sage publications.

[11] Data Collection and Survey Interviews: TNS BMRB. (2017). doi:10.4135/9781473964648

[12] DIN EN ISO 41001:2018-09, Facility Management_- Management systeme_- Anforderungen mit Anleitung für die Anwendung (ISO_41001:2018); Deutsche Fassung EN_ISO_41001:2018. (n.d.). doi: $10.31030 / 2811705$

[13] Draper, R. (2017). Standards, Regulations, and Guidelines Compliance and Your Security Program, Including Global Resources. Effective Physical Security, 301-310. doi:10.1016/b978-0-12-804462-9.00017-8

[14] Draper, R. (2017). Standards, Regulations, and Guidelines Compliance and Your Security Program, Including Global Resources. Effective Physical Security, 301-310. doi:10.1016/b978-0-12-804462-9.00017-8.

[15] Earl Babbie Discusses Social Research. (2017). doi:10.4135/9781473999411

[16] Espinosa, A., \& Kadić-Maglajlić, S. (2014). Facilitating of Emotions in Sales Interactions may Hinder Performance. International Journal of Social Science Studies, 3(1). doi:10.11114/ijsss.v3i1.578

[17] Fairgrieve, D., \& Squires QC, D. (2019). Health and Safety Regulators. The Negligence Liability of Public Authorities, Second Edition. doi:10.1093/oso/97 80199692552.003.0013

[18] Food and Drugs Authority's (FDA) code of practice for cold storage facilities , 2013

[19] H. Ozgun, B. Cicekalan, Y. Akdag, I. Koyuncu, I. Ozturk; Comparative evaluation of cost for preliminary and tertiary municipal wastewater treatment plants in Istanbul, Science of The Total Environment, Volume 778, 2021, 146258,ISSN 0048-9697,

[20] Hadi, W. R. (2019). Global Value Chain and International Alliance Strategy Review. doi:10.31219/osf.io/bvwgz

[21] Hanke, B. (2018). Controlling der Facility Management-Anforderungen. Praxishandbuch Facility Management, 271-332. doi:10.1007/978-3-658-19314-0_5

[22] Hennig, B. (2019). International scientists seek solutions for environmental problems. Reviews on Environmental Health, 34(3), 225-225. doi:10.1515/reveh-2019-0058

[24] Ishii, Y. (2013). Quality-Price Competition and Product R\&D Investment Policies in Developing and Developed Countries. Economic Record, 90(289), 197-206. doi:10.1111/1475-4932.12076

[25] Kenny, G. P., Flouris, A. D., Yagouti, A., \& Notley, S. R. (2018). Towards establishing evidence-based guidelines on maximum indoor temperatures during hot weather in temperate continental climates. Temperature, 6(1), 11-36. doi:10.1080/233289 40.2018.1456257 (2020). Standard Operating Procedure. Definitions. doi:10.32388/xvtxnt

[26] Lundgren, M., Squatrito, T. \& Tallberg, (2017) J. Stability and change in international policy-making: A punctuated equilibrium approach. Rev Int Organ 13, 547-572 (2018).

[27] Lundgren, T., \& Zhou, W. (2017). Firm performance and the role of environmental management. Journal of Environmental Management, 203, 330-341

[28] Mandy, D. M. (2017). Profit Maximization. Producers, Consumers, and Partial Equilibrium, 79-105. 
doi:10.1016/b978-0-12-811023-2.00004-9

[29] Measurement Validity. (2016). Research Methods in Applied Settings, $222-237$. doi:10.4324/9781315723082-23

[30] Michael E. Porter and Claas van der Linde (1995), "Toward a New Conception of the EnvironmentCompetitiveness Relationship", Journal of Economic Perspectives, 9, pp. 97-118. (2018). Economic Costs and Consequences of Environmental Regulation, 443-464. doi:10.4324/9781315188010-32

[31] Minimizing Alternative Explanations for Research Findings: Internal Validity. (n.d.). Quantitative Research for the Qualitative Researcher, 135-148. doi:10.4135/9781506335674.n6

[32] Cold Storage Managers in Ghana, (2021), “compliance improve the quality of products which increase trust and sales which affects profit levels positively"

[33] MISIR, G. B., KUTLU, S., \& AYYILDIZ, H. (2015). Fish Consumption Preferences of Consumers in Trabzon, Turkey. Yunus Araştırma Bülteni, 15(2). doi:10.17693/ yuus.50802

[34] MISIR, G. B., KUTLU, S., \& AYYILDIZ, H. (2015). Fish Consumption Preferences of Consumers in Trabzon, Turkey. Yunus Araştırma Bülteni, 15(2). doi:10.17693/yunus.50802

[35] Murthy, U. (2020). The Factors that Affects Corporate Liquidity of Manufacturing Firms in Malaysia: Evidences from Twenty Manufacturing Firms. International Journal of Psychosocial Rehabilitation, 24(1), 861-872. doi:10.37200/ijpr/v24i1/pr200192

[36] Mwacalimba, K. (2016). Disease Control, Public Health and Food Safety: Food Policy Lessons from SubSaharan Africa. International Food Law and Policy, 1061-1103. doi:10.1007/978-3-319-07542-6_42

[37] Myn Min Aung et al.,(2014), Volume 40, June 2014, Pages 198-207

[38] Nävy, J. (2018). Facility Management. doi:10.1007/978-3-662-56230-7 November

[39] Pharmaceutical. D. Klassen, Curtis P. McLaughlin,1996 Publication The Impact of Environmental Management on Firm Performance,

[40] Pieniak, Z., Verbeke, W., \& Scholderer, J. (2010). Health-related beliefs and consumer knowledge as determinants of fish consumption. Journal of Human Nutrition and Dietetics, 23(5), 480-488. doi:10.1111/j.1365-277x.2010.01045.x

[41] Quality management to meet regulatory requirements. (2004). Sterile Product Facility Design and Project Management, 287-306. doi:10.1201/9781420025859-12

[42] Quantitative and qualitative modes of analysis. (2016). Case Study Research, 153-192. doi:10.1017/9781316848593.009

[43] Regulators and Authorities. (2020). Data Protection, Privacy Regulators and Supervisory Authorities. doi:10.5040/9781526514240.chapter-004

[44] Robertson, D. (2016). Regulatory Agencies and Operational Risk. Managing Operational Risk, 131-158. doi:10.1007/978-1-137-44217-8_5

[45] Rose, R. (2017). Shaping Sustainable Inclusion Policy Through Practice. Oxford Research Encyclopedia of Education. doi:10.1093/acrefore/9780190264093.013.149

[46] Sakrabani, P. (2020). The Impact Of Retail 4.0 Technologies Adoption On Retailers' Performance In Malaysia. doi:10.15405/epsbs.2020.03.03.33

[47] Saunders M., Lewis P., Thornhill A. (2007) Research methods for business students (4th ed.). London, England: Prentice Hall.

[48] Scadden, J. (2019). "The Government needs to remember that good quality provision costs." Early Years Educator, 21(6), 8- 8. doi:10.12968/eyed.2019.21.6.8 costs." Early Years Educator, 21(6), 8-8. doi:10.12968/eyed.2019.21.6.8

[49] Schalck, R. (2019). Special Cleaning Processes. The Proper Care of Optics: Cleaning, Handling, Storage, and Shipping, 2019 Update. doi:10.1117/3.2518746.ch5

[50] Seidelson, C. (2021). Warehouse Pricing at a Cold Storage Facility in Indianapolis. doi:10.4135/9781529761993

[51] Stroud, B. (2019). Knowledge from a Human Point of View. Knowledge from a Human Point of View, 141148. doi:10.1007/978-3-030-27041-4_9

[52] Valbuena, D. C., Chacón, S. L. O., Torregroza-Espinosa, A. C., \& Mahecha, H. S. (2020)

[53] 2019. (2019). The ASHA Leader, 24(11), 26-27. doi:10.1044/leader.ppl.24112019.26

[54] Widarwati, E., \& Sartika, D. (2018). Is Financial Distress Cost Important For Determining Firm Performance. Proceedings of the 4th Sriwijaya Economics, Accounting, and Business Conference. doi:10.5220/0008442305400545

[55] Wu, M., Gao, X., \& Wieczorek, R. (Bob). (2019). Factors Affecting Bond Pricing and Valuation. Debt Markets and Investments, 437-452. doi:10.1093/oso/97 80190877439.003.0024

[56] Zakaria, U. S. (2018). The Determinants of Firms Profitability in Consumer Product Sectors. doi:10.15405/epsbs.2018.07.02.71

[57] Cold Storage Managers in Ghana, (2021),“compliance improve the quality of products which increase trust 
and sales which affects profit levels positively"

[58] Appiah, S.O. (2014). Enforcement of Industrial Safety Laws in Ghana: A Study of the Pioneer Food Cannery, Tema. Lambert Academic Publishing. Andioni, D. (2006). The cost of occupational Accidents and Diseases.

[59] Occupational Safety and Health Series 54, Geneva, International Labour Office.

[60] Association of Ghana Industries Report (2006), Accra: Government Printer

[61] World health Organisation (2006). The Global Burden of Diseases Harvard: Harvard University Press.

[62] Environmental management. Guidelines for establishing good practices for combatting land degradation and desertification. (n.d.). doi:10.3403/30287973

[63] Hadi, W. R. (2019). Global Value Chain and International Alliance Strategy Review. doi:10.31219/osf.io/bvwgz

[64] Annan P. R., (2015) - Compliance with Facility Management Practices and Regulatory standards among cold storage operators in the Ghanaian Fishing industry.

[65] Hanke, B. (2018). Controlling der Facility Management-Anforderungen. Praxishandbuch Facility Management, 271-332. doi:10.1007/978-3-658-19314-0_5

[66] Draper, R. (2017). Standards, Regulations, and Guidelines Compliance and Your Security Program, Including Global Resources. Effective Physical Security, 301-310. doi:10.1016/b978-0-12-804462-9.00017-8

[67] Steedman, S., Gantley, M., \& Sanders, R. (2019). Standards-based Regulation, the Role of Standards and Accreditation in Regulatory Delivery. Regulatory Delivery. doi:10.5040/9781509918614.ch-023

[68] Fisheries Act 2002 - Act 62510 May, 2016 in Laws and Regulations

[69] FDA, 2014; PNDCL 3053, ACT 1992- Food and Service Industry

[70] The public Health Act, 2012 (Act 851)-Code of good cold storage Practices in Ghana

[71] CAP 78, 1908 section 8 amended in 1935- Bye Laws of Ghana Public Health Risk

[72] FDA 2011 Guidance - Process Validation: General Principles and Practices

[73] Ghana Environmental Protection Agency Act 1994 (Act 490)

[74] ISO/IEC 9001: 2008 And 22000: 2005. - Quality Management Systems International Journals Of Academics \& Research (IJARKE Business \& Management Journal) 2019 - Effects of Working Capital Management on Profitability of Mineral Water Manufacturing Firms in Mogadishu, Somalia DOI: 10.32898/ibmj.01/1.2article04

[75] Seidelson, C. (2021). Warehouse Pricing at a Cold Storage Facility in Indianapolis. doi: $10.4135 / 9781529761993$

[76] www.iso.org/member/1747.html

[77] Hennig, B. (2019). International scientists seek solutions for environmental problems. Reviews on Environmental Health, 34(3), 225-225. doi:10.1515/reveh-2019-0058

[78] Çalı, B. (2015). The Authority of International Law. The Authority of International Law, 49-86. doi:10.1093/acprof:oso/9780199685097.003.0003

[79] Quality management to meet regulatory requirements. (2004). Sterile Product Facility Design and Project Management, 287- 306. doi:10.1201/9781420025859-12

[80] Fairgrieve, D., \& Squires QC, D. (2019). Health and Safety Regulators. The Negligence Liability of Public Authorities, Second Edition. doi:10.1093/oso/9780199692552.003.0013

[81] Pieniak, Z., Verbeke, W., \& Scholderer, J. (2010). Health-related beliefs and consumer knowledge as determinants of fish consumption. Journal of Human Nutrition and Dietetics, 23(5), 480-488. doi:10.1111/j.1365-277x.2010.01045.x

[82]MISIR, G. B., KUTLU, S., \& AYYILDIZ, H. (2015). Fish Consumption Preferences of Consumers in Trabzon, Turkey. Yunus Araştırma Bülteni, 15(2). doi:10.17693/yunus.50802

[83] AYDIN, A., \& BASHIMOV, G. (2020). Determination of Fish Consumption Habits of Consumers: Case Study of Mary City, Turkmenistan. Marine Science and Technology Bulletin, In Press, 118-124. doi:10.33714/masteb.685436 Internet

Search https://www.academia.edu/30895778/Connecting_occupational_safety_awareness_legislation_implementat ion and enforcement within the Ghanaian industrial economy。(Accessed 2021 June 12)

[84] www.iso.org/member/1747.html. (Accessed in 2021 June)

[85] https://www.grandviewresearch.com/industry-analysis/cold-storage-market. (Accessed in 2021 May)

[86]https://doi.org/10.1007/s11558-017-9288-x. (Accessed in 2021 May)

[87]https://doi.org/ 10.1016/j.scitotenv.2021.146258.

(https://www.sciencedirect. com/science/article/pii/S0048969721013267) (accessed in 2021 May) 